\title{
Unravelling interspecific relationships among highland lizards: first phylogenetic hypothesis using total evidence of the Liolaemus montanus group (Iguania: Liolaemidae)
}

\author{
CRISTIAN SIMÓN ABDALA ${ }^{1,2 *}$ ANDRÉS SEBASTIÁN QUINTEROS ${ }^{3, \oplus,}$ \\ ROMINA VALERIA SEMHAN ${ }^{1}$, ANA LUCIA BULACIOS ARROYO ${ }^{1}$, JAMES SCHULTE ${ }^{4}$, \\ MARCOS MAXIMILIANO PAZ ${ }^{1}$, MARIO RICARDO RUIZ-MONACHESI ${ }^{3}$, ALEJANDRO \\ LASPIUR $^{5}$, ALVARO JUAN AGUILAR-KIRIGIN ${ }^{6}$, ROBERTO GUTIÉRREZ POBLETE ${ }^{7}$, \\ PABLO VALLADARES FAUNDEZ ${ }^{8}$, JULIÁN VALDÉS ${ }^{9}$, SABRINA PORTELLI $^{3}$, \\ ROY SANTA CRUZ ${ }^{6}$, JAMES APARICIO ${ }^{6,10}$, NOELIA GARCIA ${ }^{1}$ and ROBERT LANGSTROTH ${ }^{6}$
}

${ }^{1}$ Consejo Nacional de Investigación Científicas y Técnicas (CONICET) - Unidad ejecutora Lillo (UEL), Tucumán, Argentina

${ }^{2}$ Facultad de Ciencias Naturales e Instituto Miguel Lillo (IML), Universidad Nacional de Tucumán, Tucumán, Argentina

${ }^{3}$ Instituto de Bio y Geociencias del NOA, Consejo Nacional de Investigación Científicas y Técnicas, Universidad Nacional de Salta, Salta, Argentina

${ }^{4}$ Department of Biology, Center for the Sciences, Beloit College, Beloit, WI, USA

${ }^{5}$ Departamento de Biología, Facultad de Ciencias Exactas Físicas y Naturales (FCEFyN) - Escuela Universitaria de Ciencias de la Salud (EUCS) - Universidad Nacional de San Juan, Consejo Nacional de Investigaciones Científicas y Técnicas, Rivadavia, San Juan, Argentina

${ }^{6}$ Área de Herpetología, Colección Boliviana de Fauna, Campus Universitario de Cota Cota, Facultad de Ciencias Puras y Naturales, Universidad Mayor de San Andrés, La Paz, Estado Plurinacional de Bolivia ${ }^{7}$ Museo de Historia Natural, Universidad Nacional de San Agustín, Arequipa, Peru

${ }^{8}$ Laboratorio de Zoología Integrativa, Departamento de Biología, Facultad de Ciencias, Universidad de Tarapacá, Arica, Chile

${ }^{9}$ Cátedra Genética Evolutiva, Facultad de Ciencias Exactas y Naturales y Agrimensura, Universidad Nacional del Nordeste, Corrientes, Argentina

${ }^{10}$ Museo Nacional de Historia Natural (MNHN), Cota Cota (Ovidio Suárez), La Paz, Bolivia

Received 30 April 2019; revised XX XXXX XXXX; accepted for publication 5 September 2019

The South American lizard genus Liolaemus comprises > 260 species, of which > 60 are recognized as members of the Liolaemus montanus group, distributed throughout the Andes in central Peru, Bolivia, Chile and central Argentina. Despite its great morphological diversity and complex taxonomic history, a robust phylogenetic estimate is still lacking for this group. Here, we study the morphological and molecular diversity of the L. montanus group and present the most complete quantitative phylogenetic hypothesis for the group to date. Our phylogeny includes 103 terminal taxa, of which 91 are members of the L. montanus group (58 are assigned to available species and 33 are of uncertain taxonomic status). Our matrix includes 306 morphological and ecological characters and 3057 molecular characters. Morphological characters include 48 continuous and 258 discrete characters, of which $70 \%$ (216) are new to the literature. The molecular characters represent five mitochondrial markers. We performed three analyses: a morphology-only matrix, a molecular-only matrix and a matrix including both morphological and molecular characters (total evidence hypothesis). Our total evidence hypothesis recovered the L. montanus group as monophyletic and included $\geq 12$ major clades, revealing an unexpectedly complex phylogeny.

*Corresponding author. E-mail: samiryjazmin@gmail.com 
ADDITIONAL KEYWORDS: Bayesian analysis - cladistic analysis - lizard - morphological phylogenetics molecular phylogeny - parsimony analysis - South America - Taxonomy.

\section{INTRODUCTION}

The genus Liolaemus Wiegmann, 1834 currently includes 267 species of lizards (updated from Gutiérrez et al., 2018) that are distributed from Tierra del Fuego in southern Argentina and Chile to central Peru. The most widely accepted phylogenetic hypothesis for Liolaemus is that of Schulte et al. (2000), which provided molecular support to Laurent's (1983) division of the genus into two subgenera: Liolaemus s.s. (or the 'Chilean group') and Eulaemus 1858 (or the 'Argentinean group'). It was Etheridge (1995) who first proposed the division of the genus into groups based on morphological synapomorphies. Various arrangements of species groups have been proposed within Eulaemus, as summarized in Table 1. Etheridge (1995) proposed the Liolaemus montanus group for species with the following combination of characters: presence of pigmented epimysium of the $\mathrm{m}$. pterygomandibularis, medial head of $\mathrm{m}$. flexor tibialis internus covered by hypetrophied $\mathrm{m}$. tibials anticus (Abdala et al., 2006), a sharp, bladelike process on the posterior distal tibia, associated with a greatly hypertrophied $\mathrm{m}$. tibialis anterior and the absence of a patch of enlarged scales located in the posterior region of the thigh.

Since the first formal phylogenetic hypothesis for Liolaemus (Ortiz, 1981), several phylogenies for the genus have been proposed (Young-Downey, 1998; Etheridge, 1995; Schulte et al., 2000; Espinoza et al., 2004). Likewise, phylogenies have been proposed for different groups and subgroups of the genus; for example, Liolaemus s.s. (Morando, 2004; Medina et al., 2014), Eulaemus (Fontanella et al., 2012; Olave et al., 2014), the Liolaemus boulengeri group (Avila et al., 2006; Abdala, 2007), the Liolaemus lineomaculatus group (Breitman et al., 2011, 2013), the Liolaemus elongatus-kriegi group (Lobo, 2001, 2005), the Liolaemus alticolor-bibronii group (Morando et al., 2007; Quinteros, 2013; Portelli \& Quinteros, 2018), the Liolaemus anomalus group (Abdala \& Juarez Heredia, 2013) and the Liolaemus archeforus-kingii group (Breitman et al., 2015). The most inclusive phylogenies of Squamata (Pyron et al., 2013; Zheng \& Wiens, 2016) or Liolaemus broadly (Schulte et al., 2000; Valladares et al., 2002; Espinoza et al., 2004; Schulte, 2013; Olave et al., 2014) have included some species of the L. montanus Koslowsky, 1898 , group, but never $>25 \%$ of the members of this group. Aguilar et al. (2017) performed an integrative taxonomical study including a phylogeny of the species (21 terminal taxa) of the L. montanus group from Peru, and Aguilar-Puntriano et al. (2018) included 57 terminals corresponding to 43 available names and 14 candidate species of the L. montanus group, including populations from Bolivia, Chile and Argentina. Several informal phylogenetic hypotheses have been proposed (Cei, 1986, 1993; Pincheira-Donoso \& Núñez, 2005; Díaz Gómez, 2007; Pincheira-Donoso et al., 2008; Lobo et al., 2010a), but these proposals were not based on quantitative phylogenetic methods and were based on few morphological characters. As illustrated in Table 2, the L. montanus group has had a complex taxonomic history, with several genera erected and eliminated, and numerous unresolved synonymies and debates on the identities of poorly understood species, all in the absence of a robust phylogenetic hypothesis.

The species of the L. montanus group are found from central Peru to central-west Argentina, also occupying areas of northern Chile and the Andean region of Bolivia (Fig. 1). These taxa largely inhabit high elevations (2500-5000 m a.s.l.) in Andean, pre-Puna and Puna regions, with some additional taxa in lower-elevation arid regions of the Pacific slope of Chile and Peru (Fig. 1; Abdala \& Quinteros, 2014). The L. montanus group includes species that are more widely distributed, such as Liolaemus orientalis Müller, 1924 (Puna of Argentina and Bolivia), Liolaemus schmidti Marx, 1960 (Puna of south-western Bolivia and Chile) and Liolaemus signifer (Duméril \& Bibron, 1837) (Puna of Bolivia and Peru). In contrast, there are numerous species with a marked endemism, such as Liolaemus halonastes Lobo et al., 2010a (southern region of Salar de Arizaro, Argentina), Liolaemus porosus Abdala et al., 2013 (around Volcán Socompa, Argentina and Chile) and Liolaemus fittkaui Laurent, 1986 (humid Puna of Cochabamba, Bolivia). Also, there are endemics along the Sierras Pampeanas of Argentina: Liolaemus famatinae Cei, 1980 (Sierra de Famatina), Liolaemus huacahuasicus Laurent, 1985 (Sierra de Aconquija) and Liolaemus orko Abdala \& Quinteros, 2008 (Sierra de Fiambalá). Most of the members of the L. montanus group are distributed in Chile (27 species; Demangel, 2016), followed by 25 in Argentina (Abdala \& Quinteros, 2014), 13 in Bolivia (Etheridge \& Frost, 2010; Aguilar-Kirigin et al., 2016) and 15 in Peru (Aguilar et al., 2019) (Table 3). In recent years, there have been many studies on the distribution of species 
Table 1. Summary of the proposed groupings within the subgenus Eulaemus

\begin{tabular}{|c|c|c|c|}
\hline Author & $\begin{array}{l}\text { Subgenus or } \\
\text { Supergroup }\end{array}$ & Section or main group & Clade or series or group \\
\hline Laurent $(1983,1985)$ & Eulaemus & & $\begin{array}{l}\text { L. fitzingerii group } \\
\text { L. signifer group }\end{array}$ \\
\hline Cei $(1986,1993$ & Supergroup Argentina & & $\begin{array}{l}\text { L. andinus group } \\
\text { L. montanus group } \\
\text { L. ruibali group } \\
\text { L. signifer group }\end{array}$ \\
\hline Etheridge (1995) & signifer group & L. montanus group & $\begin{array}{l}\text { L. boulengeri group, } \\
38 \text { taxa }\end{array}$ \\
\hline Schulte et al. (2000) & Eulaemus & $\begin{array}{l}\text { L. montanus section } \\
\text { L. lineomaculatus section* }\end{array}$ & $\begin{array}{l}\text { L. boulengeri series } \\
\text { L. montanus series }\end{array}$ \\
\hline Pincheira-Donoso \& Núñez (2005)‡ & Eulaemus & $\begin{array}{l}\text { L. fitzingerii complex } \\
\text { L. signifer complex }\end{array}$ & $\begin{array}{l}\text { L. darwinii group } \\
\text { L. fitzingerii group } \\
\text { L. fabiani group } \\
\text { L. jamesi group } \\
\text { L. ruibali group } \\
\text { L. signifer group }\end{array}$ \\
\hline Pincheira-Donoso et al. (2008) & Eulaemus & & $\begin{array}{l}\text { L. montanus clade } \\
\text { L. anomalus clade } \\
\text { L. boulengeri clade }\end{array}$ \\
\hline Lobo et al. (2010a) & Eulaemus & $\begin{array}{l}\text { L. montanus section } \\
\text { L. lineomaculatus section* } \\
\text { unnamed clade } \dagger\end{array}$ & $\begin{array}{l}\text { L. montanus series } \\
\text { L. boulengeri series }\end{array}$ \\
\hline Olave et al. $(2012,2014 \S$ & Eulaemus & $\begin{array}{l}\text { L. montanus section } \\
\text { lineomaculatus section }\end{array}$ & $\begin{array}{l}\text { L. melanops series } \\
\text { L. anomalus series } \\
\text { L. montanus group } \\
\text { L. darwinii group } \\
\text { L. wiegmannii group }\end{array}$ \\
\hline Fontanella et al. $(2012) \S$ & Eulaemus & $\begin{array}{l}\text { L. montanus section } \\
\text { L. lineomaculatus section }\end{array}$ & $\begin{array}{l}\text { L. melanops series } \\
\text { L. boulengeri complex } \\
\text { L. rothi complex } \\
\text { L. donosobarrosi complex } \\
\text { L. fitzingerii complex } \\
\text { L. nigriceps series } \\
\text { L. montanus group } \\
\text { L. darwinii group } \\
\text { L. anomalus group } \\
\text { L. wiegmannii group }\end{array}$ \\
\hline Schulte et al. (2013) & Eulaemus & $\begin{array}{l}\text { L. montanus section } \\
\text { L. lineomaculatus section }\end{array}$ & $\begin{array}{l}\text { L. montanus series } \\
\text { L. wiegmannii series } \\
\text { L. melanops group } \\
\text { L. darwinii complex }\end{array}$ \\
\hline
\end{tabular}

Modified from Quinteros \& Abdala (2011).

*The L. lineomaculatus section resembles the L. lineomaculatus group of Etheridge (1995), but the latter is located in the subgenus Liolaemus s.s. $\dagger$ Includes the L. magellanicus and the L. kingii-archeforus groups.

\$Classification based on character combination, not on a formal cladistic analysis.

$¥$ Recovers the L. boulengeri group (sensu Abdala, 2007; Schulte et al., 2000) as paraphyletic. See main text for details.

in the L. montanus group (Aparicio \& Ocampo, 2010; Paz et al., 2013; Ruiz de Gamboa Astroza \& González, 2013; Troncoso-Palacios \& Ferri-Yáñez, 2013; Díaz-Vega, 2014; Aguilar-Kirigin et al., 2016; Aguilar-Kirigin \& Abdala, 2016; Jiménez-Robles, 2016), allowing us to gain a better understanding of the latitudinal and elevational distributions and the environments that they inhabit. Some species of the L. montanus group were included in biogeographical studies (Díaz Gómez, 2007; Quinteros \& Díaz Gómez, 2011; Andrade-Díaz et al., 2017), aiding further knowledge. 
Table 2. Historical nomenclatural acts proposed for members of the Liolaemus montanus group

\begin{tabular}{|c|c|c|c|}
\hline Current taxonomic state & Proposal & Authors (year) & Nomenclatural act \\
\hline & Ctenoblepharis audituvelatus & Núñez \& Yáñez (1983) & Original description \\
\hline \multirow[t]{3}{*}{ Liolaemus audituvelatus } & Phrynosaura audituvelata & Laurent (1984) & Assigned to Phrynosaura \\
\hline & Liolaemus audituvelatus & Etheridge (1995) & Assigned to Liolaemus \\
\hline & Velosaura aymararum & Núñez \& Yañez (1984) & Assigned to a new genus \\
\hline \multirow[t]{3}{*}{ Liolaemus aymararum } & Liolaemus aymararum & Laurent (1984) & Assigned to a new genus \\
\hline & Liolaemus jamesi & Pincheira-Donoso \& Núñez (2005) & Synonym \\
\hline & Liolaemus aymararum & Langstroth (2011) & Revalidation \\
\hline \multirow[t]{3}{*}{ Liolaemus erguetae } & Liolaemus islugensis erguetae & Laurent (1995) & Original description \\
\hline & Liolaemus erguetae & Pincheira-Donoso \& Núñez (2002) & Assigned to species status \\
\hline & Ctenoblepharys erroneus & Núñez \& Yáñez (1984) & Original description \\
\hline \multirow[t]{3}{*}{ Liolaemus erroneus } & Phrynosaura erroneus & Pincheira-Donoso (2005) & Assigned to a new genus \\
\hline & Liolaemus erroneus & Pincheira-Donoso et al. (2008) & Assigned to a new genus \\
\hline & Abas fabiani & Núñez \& Yáñez (1984) & Assigned to a new genus \\
\hline \multirow[t]{2}{*}{ Liolaemus fabiani } & Ceiolaemus fabiani & Veloso \& Navarro (1988) & Assigned to a new genus \\
\hline & Liolaemus fabiani & Laurent (1992) & Assigned to a new genus \\
\hline \multirow[t]{2}{*}{ Liolaemus filiorum } & Liolaemus puritamensis & Troncoso-Palacio (2014) & Synonym \\
\hline & Liolaemus filiorum & Pincheira-Donoso (2014) & Revalidation \\
\hline \multirow[t]{3}{*}{ Liolaemus insolitus } & Abas insolitus & Núñez \& Yáñez (1984) & Assigned to a new genus \\
\hline & Liolaemus insolitus & Etheridge (1995) & Assigned to a new genus \\
\hline & Ctenoblepharis jamesi & Boulenger (1891) & Original description \\
\hline \multirow[t]{3}{*}{ Liolaemus jamesi } & Liolaemus jamesi & Cei (1979) & Assigned to a new genus \\
\hline & Velosaura jamesi & Núñez \& Yáñez (1984) & Assigned to a new genus \\
\hline & Liolaemus jamesi & Etheridge (1995) & Assigned to a new genus \\
\hline \multirow[t]{2}{*}{ Liolaemus manueli } & Phrynosaura manueli & Núñez et al., 2003 & Original description \\
\hline & Liolaemus manueli & Schulte et al. (2004) & Assigned to a new genus \\
\hline \multirow[t]{3}{*}{ Liolaemus molinai } & Liolaemus andinus & Pincheira-Donoso \& Núñez (2005) & Synonym \\
\hline & Liolaemus molinai & Lobo et al. (2010) & Revalidation \\
\hline & Helocephalus nigriceps & Philippi (1860) & Original description \\
\hline \multirow[t]{3}{*}{ Liolaemus nigriceps } & Liolaemus signifer var. nigriceps & Koslowsky (1898) & Assigned to a new genus \\
\hline & Ctenoblepharis nigriceps & Donoso-Barros (1966) & Assigned to a new genus \\
\hline & Liolaemus nigriceps & Laurent (1984) & Assigned to a new genus \\
\hline \multirow[t]{2}{*}{ Liolaemus orientalis } & Liolaemus annectens orientalis & Müller (1924) & Original description \\
\hline & Liolaemus orientalis & Laurent (1992) & Assigned to species status \\
\hline \multirow[t]{2}{*}{ Liolaemus chlorostictus } & Liolaemus orientalis chlorostictus & s Laurent (1991) & Original description \\
\hline & Liolaemus chlorostictus & Schulte et al., 2000 & Assigned to species status \\
\hline \multirow[t]{2}{*}{ Liolaemus pachecoi } & Liolaemus jamesi pachecoi & Laurent (1995) & Original description \\
\hline & Liolaemus pachecoi & Langstroth (2011) & Assigned to species status \\
\hline Liolaemus pantherinus & Liolaemus islugensis & Pincheira-Donoso \& Núñez (2005) & Synonym \\
\hline \multirow[t]{4}{*}{ Liolaemus poecilochromus } & Liolaemus andinus & Pincheira-Donoso \& Núñez (2005) & Synonym \\
\hline & Liolaemus poecilochromus & Lobo et al. (2010b) & Revalidation \\
\hline & Phrynosaura reichei & Werner (1907) & Original description \\
\hline & Ctenoblepharys reichei & Donoso-Barros (1972) & Assigned to a new genus \\
\hline \multirow[t]{4}{*}{ Liolaemus reichei } & Liolaemus reichei & Etheridge (1995) & Assigned to a new genus \\
\hline & Liolaemus stolzmanni & Langstroth (2011) & Synonym \\
\hline & Liolaemus reichei & Valladares et al. (2018) & Revalidation \\
\hline & Ctenoblepharis schmidti & $\operatorname{Marx}(1960)$ & Original description \\
\hline \multirow[t]{6}{*}{ Liolaemus schmidti } & Liolaemus andinus & Pincheira-Donoso \& Núñez (2005) & Synonym \\
\hline & Liolaemus schmidti & Lobo et al. (2010b) & Revalidation \\
\hline & Proctotretus Signifer & Duméril \& Bibron (1837) & Original description \\
\hline & Ptychodeira signifera & Fitzinger (1843) & Assigned to a new genus \\
\hline & Leiolaemus signifer & Gray (1845) & Assigned to a new genus \\
\hline & Eulaemus signifer & Girard (1858) & Assigned to a new genus \\
\hline
\end{tabular}


Table 2. Continued

\begin{tabular}{llll}
\hline Current taxonomic state & Proposal & Authors (year) & Nomenclatural act \\
\hline \multirow{2}{*}{ Liolaemus signifer } & Proctotretus multiformis & Cope (1875) & Assigned to a new genus \\
& Liolaemus multiformis & Halloy \& Laurent (1988) & Synonym \\
& Liolaemus lenzi & Burt \& Burt (1931) & Synonym \\
& Liolaemus variabilis var. Crequii & Peters \& Donoso-Barros (1970) & Synonym \\
& Liolaemus variabilis var. Neveui & Peters \& Donoso-Barros (1970) & Synonym \\
& Liolaemus variabilis var. Courtyi & Peters \& Donoso-Barros (1970) & Synonym \\
& Liolaemus bolivianus & Donoso-Barros (1966) & Synonym \\
& Ctenoblepharis Stolzmanni & Steindachner (1891) & Original description \\
Liolaemus stolzmanni & Phrynosaura stolzmanni & Laurent (1984) & Assigned to a new genus \\
& Liolaemus stolzmanni & Etheridge (1995) & Assigned to a new genus \\
& Liolaemus reichei & Langstroth (2011) & Synonym \\
& Phrynosaura torresi & Núñez et al. (2003) & Original description \\
Liolaemus torresi & Liolaemus torresi & Pincheira-Donoso et al. (2008) & Assigned to a new genus \\
& Liolaemus multiformus & Burt \& Burt (1931) & Synonym \\
& Liolaemus signifer & Laurent (1984) & Synonym
\end{tabular}

We included only those species members of the L. montanus group that show nomenclatural acts. We have not included a complete list of synonyms (see Etheridge \& Frost, 2010).

The aim of this work is to elucidate the evolutionary relationships and species richness of the $L$. montanus group further by obtaining more robust and comprehensive phylogenetic hypotheses based on the available total evidence, including morphological, ecological, biogeographical and molecular evidence. Additionally, we use these hypotheses to clarify some outstanding taxonomic issues in the L. montanus group.

\section{MATERIAL AND METHODS}

\section{SPECIMEN COLLECTION AND PREPARATION}

More than 600 specimens of Liolaemus were collected during 24 collecting trips in Argentina, Bolivia, Chile and Peru, all with the required national or provincial authorizations required for scientific collections of fauna in each country. We were able to collect specimens of the majority of the described species of the $L$. montanus group, plus $>100$ specimens of uncertain taxonomic status but clearly belonging to the group. We prioritized collections from the type localities of described species to prevent regional variability. Specimens were captured with a noose, with a fork or by hand, avoiding the use of harmful methods (handgun, stones, etc.) in order to maintain integrity of the samples. During fieldwork, we also obtained data on the coloration in life by description and digital photography. Specimens were killed with $1 \%$ sodium pentothal, then injected with $10 \%$ formaldehyde and preserved in $70 \%$ alcohol. All procedures were conducted in accordance with international standards on animal welfare and were compliant with national regulations and the 'Comité Nacional de Ética en la Ciencia y la Tecnología' of Argentina (Expte. 5344/99 Res. 1047). Most samples were deposited in the herpetological collections of Fundación Miguel Lillo (FML), Colección Boliviana de Fauna (CBF), Museo de Historia Natural de la Universidad Nacional de San Agustín, Arequipa (MUSA) and Museo de Ciencias Naturales, Salta (MCN).

We included 56 described species $(87.5 \%)$ of the L. montanus group and an additional 37 terminal taxa belonging to the group, but which were not assignable to any available names. We did not include Liolaemus chiribaya, Aguilar et al., 2019, Liolaemus duellmani Cei, 1978, Liolaemus erroneus Núñez \& Yáñez, 1983, Liolaemus nazca, Aguilar et al., 2019, Liolaemus omorfi Demangel et al., 2015, Liolaemus pantherinus Pellegrin, 1909 and Liolaemus victormoralesi, Aguilar et al., 2019, because we did not have access to specimens of these species, some of which are known reliably only from type material, which is lost in the case of $L$. erroneus. As outgroup taxa, we include members of each of the genera included in Liolaemidae and different groups of Liolaemus: Ctenoblepharys adspersa (Tschudi, 1845), Phymaturus palluma (Molina, 1782), Liolaemus abaucan Etheridge, 1993, Liolaemus inacayali Abdala, 2013, Liolaemus kingii (Bell, 1843), Liolaemus kolengh Abdala \& Lobo, 2006, Liolaemus pseudoanomalus (Cei, 1981), Liolaemus robertmertensi Hellmich, 1964 and Liolaemus tiranti Avila et al., 2017. Specimens studied are listed in the Supporting Information (Appendix S1). 


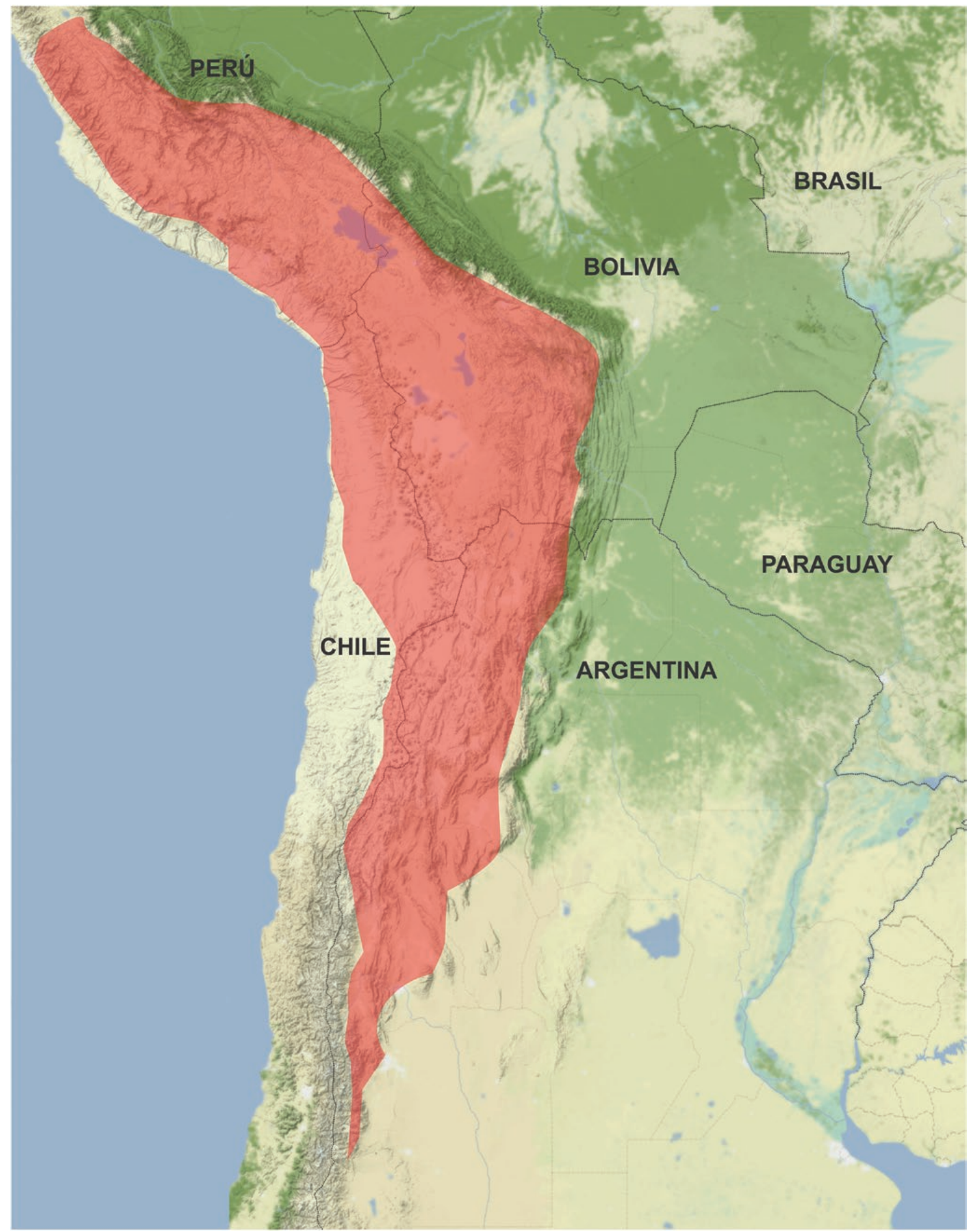

Figure 1. Map showing distribution of the Liolaemus montanus group.

\section{DATA MATRIX}

\section{Morphological characters}

We included a combination of characters based on lepidosis, morphometrics and coloration. Lepidosis was studied under a stereoscope $(\times 10-\times 40)$. Morphometric characters were measured with $\mathrm{a} \pm 0.01 \mathrm{~mm}$ precision digital calliper. Coloration was based on photographs of live animals and was analysed in conjunction with direct observation of preserved specimens. Terminology of colour patterns is shown in Figure 2. Terminology 
Table 3. Political distribution of the valid species of the Liolaemus montanus group

\begin{tabular}{|c|c|c|c|}
\hline Argentina (25) & Bolivia (13) & Chile (31) & Peru (15) \\
\hline L. cazianiae & L. chlorostictus & L. andinus & L. annectens \\
\hline L. chlorostictus & L. erguetae & L. audituvelatus & L. chiribaya \\
\hline L. dorbignyi & L. fittkaui & L. erguetae & L. etheridgei \\
\hline L. duellmani & L. forsteri & L. erroneus & L. evaristoi \\
\hline L. eleodori & L. islugensis & L. fabiani & L. insolitus \\
\hline L. famatinae & L. jamesi & L. foxi & L. melanogaster \\
\hline L. gracielae & L. pachecoi & L. hajeki & L. nazca \\
\hline L. griseus & L. orientalis & L. islugensis & L. poconchilensis \\
\hline L. halonastes & L. pantherinus & L. jamesi & L. polystictus \\
\hline L. huacahuasicus & L. pleopholis & L. manueli & L. robustus \\
\hline L. huayra & L. puritamensis & L. molinai & L. signifer \\
\hline L. inti & L. schmidti & L. nigriceps & L. thomasi \\
\hline L. montanus & L. signifer & L. omorfi & L. victormoralesii \\
\hline L. multicolor & & L. pachecoi & L. williamsi \\
\hline L. nigriceps & & L. pantherinus & \\
\hline L. orientalis & & L. patriciaiturrae & \\
\hline L. orko & & L. pleopholis & \\
\hline L. poecilochromus & & L. poconchilensis & \\
\hline L. porosus & & L. porosus & \\
\hline L. pulcherrimus & & L. puritamensis & \\
\hline L. puritamensis & & L. reichei & \\
\hline L. ruibali & & L. robertoi & \\
\hline L. scrocchii & & L. rosenmanni & \\
\hline L. vallecurensis & & L. schmidti & \\
\hline \multirow[t]{3}{*}{ L. vulcanus } & & L. signifer & \\
\hline & & L. stolzmanni & \\
\hline & & L. torresi & \\
\hline
\end{tabular}

The species distributed in more than one country are shown in bold. The number of species per country is shown in parentheses.

used to reference anatomical and biological character states was compiled from the literature (Etheridge, 1995; Lobo \& Espinoza, 1999; Abdala, 2007; Paz, 2012; Quinteros, 2012; Abdala \& Juárez Heredia, 2013; among others) (Supporting Information, Appendix S2). We studied 306 morphological characters, including 90 from other authors (Lobo \& Quinteros, 2005; Abdala, 2007; Abdala \& Juárez Heredia, 2013; Quinteros, 2013; Gutiérrez et al., 2018) and 216 that we used for the first time in a phylogenetic analysis (see Results for details).

\section{Molecular characters}

The phylogenetic analysesincluded fivemitochondrial markers. We included $12 \mathrm{~S}$ and Cytbsequences taken from Aguilar et al. (2017). We also include sequences of the mitochondrially encoded region spanning $N D 1$ to COI taken from (Schulte et al., 2000, 2003a, b; Schulte, 2013). For newly reported DNA sequences, genomic DNA extraction, polymerase chain reaction conditions, primers used and sequencing were performed following Schulte et al. (2003a, b). These sequences represented the mitochondrially encoded region spanning $N D 1$ to $C O I$. For this analysis, only the protein-coding regions, part of $N D 1$, all of $N D 2$ and part of $C O I$ were used, given that the intervening tRNA regions were highly variable among sampled taxa, making alignment of these regions unreliable. Base positions inferred to have ambiguous homology at the ends of ND1 and ND2 were excluded from phylogenetic analyses. In total, we included 3084 aligned positions (663 from 12S, 643 from $C y t b$ and 1751 from $N D 1, N D 2$ and $C O I$ ). Sequences were aligned and edited with MEGA v.7.0.26 (Kumar et al., 2016). See the Supporting Information (Appendix S3) for the GenBank accession numbers of specimens.

\section{DATA MATRIX}

Three matrices were made:(1)including morphological data only; (2) with molecular characters only; and (3) including both morphological and molecular data. The morphological matrix included 103 terminals and 306 characters, of which 48 were continuous 


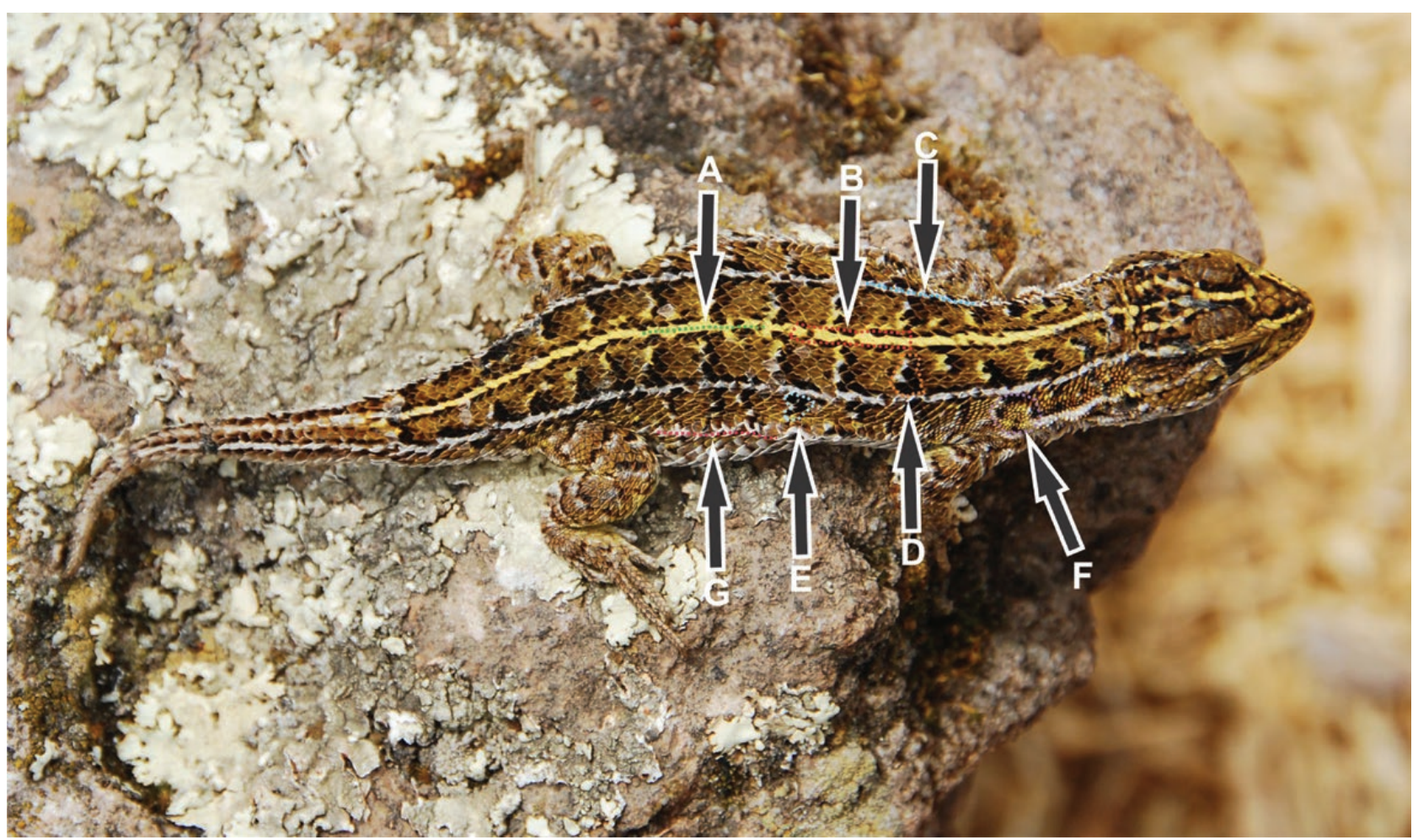

Figure 2. Regions of body of colour pattern used in the present study, modified from Lobo \& Espinoza (1999). A, vertebral line. B, vertebral field. C, dorsolateral stripes. D, paravertebral spots. E, lateral spots. F, scapular region. G, ventrolateral line.

and 258 discrete characters. The discrete characters included 143 from coloration, 95 from lepidosis and morphometrics, 16 miscellaneous (osteological, myological and lepidosis) and four ecological or biogeographical. Discrete characters were coded as non-polymorphic binary, polymorphic binary, nonpolymorphic multistate or polymorphic multistate. The polymorphic binary characters and polymorphic multistate characters were treated according to Wiens (1995). Characters $33,42,45,46,48,49,53$, $55-62,64,65,71-73,78,81-83,87,88,107,121$, 122 and 140 were considered additive. Continuous characters were analysed following Goloboff $e t a l$. (2006), avoiding any discretization. Continuous characters were standardized using the command 'nstates stand' in TNT v.1.5 (Goloboff et al., 2000, 2008; Goloboff \& Catalano, 2016). Characters 142 and 306 were discretized under the criterion by Thiele (1993). The molecular matrix included 49 taxa and 3084 bp (Supporting Information, Appendix S3). The total evidence matrix included 103 terminals and 3390 characters, adding 3084 molecular characters to the dataset. The morphological matrix in the total evidence analysis received the same treatment as in the morphological analysis.

\section{CLADISTIC ANALYSIS}

To perform the morphological and total evidence analyses, we used TNT v.1.5, with parsimony as the optimality criterion, following Farris (1983). We followed the protocol of Mirande (2008, 2009, 2010) to obtain topologies based on the most stable concavity constant $(K)$ values. Group support was estimated using symmetric resampling, with 1000 replicates and a probability of deletion of 0.33 .

For the Bayesian analysis, we selected the bestfitting model for each individual gene with JModelTest v.0.1.1 (Guindon \& Gausel, 2003; Posadas, 2008), using the corrected Akaike information criterion. We used Bayesian inference (BI) to infer a phylogenetic hypothesis and to estimate nodal support of the concatenated matrix. Bayesian inference analyses were conducted using MrBayes v.3.2 (Ronquist \& Huelsenbeck, 2003), and the parameters for all the runs were as follows: $\mathrm{mcmc}$ ngen $=50000000$, printfreq $=1000$, samplefreq $=1000$, nruns $=2$, nchains $=4$ and savebrlens = yes. Equilibrium samples (after 25\% of burn-in) were used to generate a $50 \%$ majority-rule consensus tree; posterior probabilities $(\mathrm{Pp})$ were considered significant when $\geq 0.95$ (Huelsenbeck \& Ronquist, 2001). 


\section{RESULTS}

\section{LIST OF CHARACTERS STUDIED}

Of the total number of morphological characters used, 216 were new and were derived from the results of this work. They are listed in the Supporting Information (Appendix S4).

\section{TOTAL EVIDENCE HYPOTHESIS}

Our total evidence hypothesis (TEH) was based on the combined morphological and molecular matrix. All runs recovered a monophyletic L. montanus group. Various hypotheses were obtained with different topologies and clade compositions depending on the $K$ values used. Based on the criteria proposed by Mirande (2009), we selected the most stable phylogenetic hypothesis $(K=18)$. This same hypothesis was recovered with $K$ values of $16-22$. Thus, the proposed hypothesis was highly congruent with the hypotheses obtained when $K=9-15$, recovering the same groups but with some differences in the composition and relationships among the terminals (Fig. 3).

In the proposed TEH, the Liolaemus montanus group was supported by $26 \mathrm{bp}$ and 24 morphological characters, of which 15 were continuous and nine discrete (Supporting Information, Table S1). In the L. montanus group, the species were grouped into 12 clades (Fig. 3) that we named as species groups based on the earliest available name within the group and/or following the proposals of Cei $(1986,1993)$, Díaz Gómez (2007) and Lobo et al. (2010a) (Table 4). The following species group clades were recovered (Fig. 3): (Liolaemus chlorostictus clade (Liolaemus andinus clade (Liolaemus multicolor clade (Liolaemus poecilochromus clade (Liolaemus erguetae clade + Liolaemus reichei clade) + (Liolaemus jamesi clade (Liolaemus dorbignyi clade (Liolaemus forsteri clade + Liolaemus ortizi clade) + (Liolaemus robustus clade + L. huacahuasicus clade)))))).

\section{Liolaemus chlorostictus clade}

This clade is composed of two species: Liolaemus chlorostictus Laurent, 1991 and L. orientalis. They are medium to large in size [maximal snout-vent length $(\mathrm{SVL})>90 \mathrm{~mm}$ ]. The dorsal scales of the torso are juxtaposed and weakly keeled; they possess $\leq 70$ scales around the midbody, 75 dorsals and 90 ventrals. The speciesareallopatricallydistributedinbothnorthernmost Argentina and southwestern Bolivia (Fig. 4). This clade is supported by six continuous characters and 16 discrete characters (12 lepidosis characters, three coloration characters and one ecological character; Supporting Information, Table S1). This relationship was recovered in all of the TEH runs performed.

\section{Liolaemus andinus clade}

This clade is composed of 20 terminals, of which 12 correspond to described species and eight represent populations of uncertain taxonomic status (Fig. 3). The majority of these species are distributed in Andean regions, primarily in Argentina and Chile (Fig. 5). It includes medium-sized lizards, but some species reach a SVL of $90 \mathrm{~mm}$ [i.e. Liolaemus nigriceps (Philippi, 1860) and Liolaemus patriciaiturrae Navarro \& Núñez, 1993], with smooth to weakly keeled body scales, largely juxtaposed or subimbricate, high scale counts around the midbody $(\leq 120)$, dorsals $\leq 115$ and ventrals $\leq 120$. This clade is supported by two continuous characters, two lepidosis characters, one colour character and 12 molecular characters (Supporting Information, Table S1). This clade was recovered in all of the runs performed, with variations of the internal topology.

\section{Liolaemus multicolor clade}

This clade is composed of two described species (L. multicolor Koslowski, 1898 and L. schmidti) and one terminal from a population of uncertain taxonomic status (L. aff. multicolor) (Fig. 3). These are mediumsized lizards (maximal SVL $=82 \mathrm{~mm}$ ) with smooth, juxtaposed dorsal body scales, $\leq 85$ scales around midbody and 100 ventrals, with the presence of blue scales on the dorsum, flanks and tail. These species inhabit the Puna of north-western Argentina, southwestern Bolivia and north-eastern Chile (Fig. 5). This clade is supported by one continuous character, one discrete character, five colour characters and 19 molecular characters (Supporting information, Table $\mathrm{S} 1)$. This clade was recovered in all runs performed and in the hypotheses where $K=13-15$. It is sister to the L. poecilochromus clade.

\section{Liolaemus poecilochromus clade}

This clade is composed of three described species (Liolaemus pleopholis Laurent, 1998(L.poecilochromus Laurent, $1986+$ L. halonastes)) (Fig. 3). They are medium-sized lizards, but L. pleopholis exceeds $85 \mathrm{~mm}$ (maximal SVL), possessing smooth, juxtaposed dorsals, with $\leq 90$ scales around the midbody. These species are distributed in north-western Argentina, north-eastern Chile and adjacent Bolivia (Fig. 5). The clade is supported by six continuous characters and five colour characters (Supporting Information, Table $\mathrm{S} 1)$. This clade was not recovered in the hypotheses where $K=3-11$ (only the relationship between L. poecilochromus and L. halonastes was maintained), but where $K=13-15$, this clade was recovered as sister to the multicolor clade. 


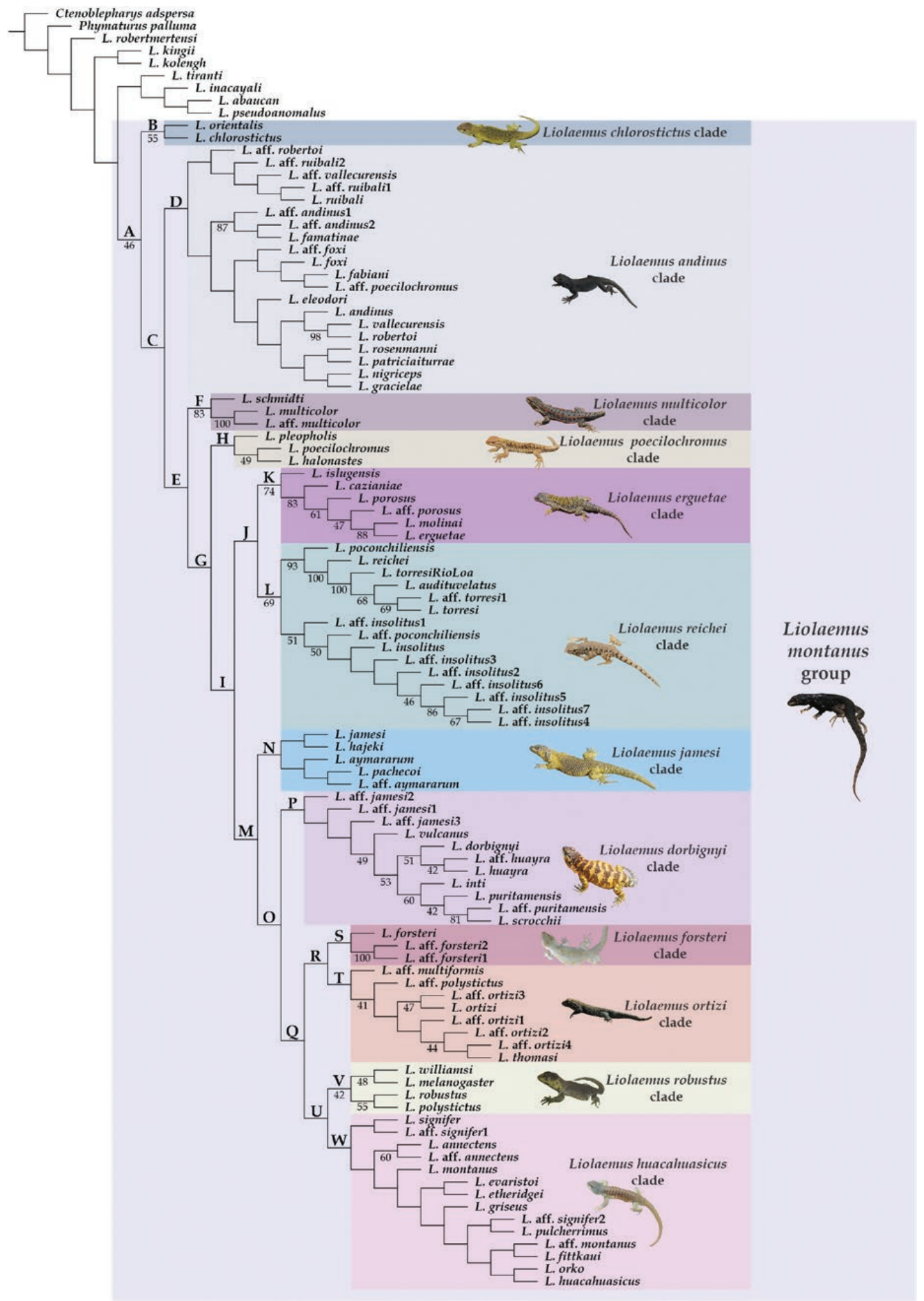

Figure 3. Total evidence hypothesis. Topology recovered by total evidence analysis under parsimony. Numbers below branches correspond to symmetric resampling.

Liolaemus erguetae clade

This clade is composed of five described species (Liolaemus cazianiae Lobo et al., 2010a, Liolaemus erguetae Laurent, 1995, Liolaemus islugensis Ortiz \&
Marquet, 1987, Liolaemus molinai Valladares et al., 2002 and $L$. porosus) and one terminal from a population of uncertain taxonomic status, $L$. aff. porosus (Fig. 3). These lizards are of small to medium size (maximal 
Table 4. Indented list of Liolaemus montanus group

A. L. montanus group
B. L. chlorostictus clade
C. Unnamed node
D. L. andinus clade
E. Unnamed node
F. L. multicolor clade
G. Unnamed node
H. L. poecilochromus clade
I. Unnamed node
J. Node: L. erguetae clade + L. reichei clade
K. L. erguetae clade
L. L. reichei clade
M. Unnamed node
N. L. jamesi clade
O. Unnamed node
P. L. dorbignyi clade
Q. Unnamed node
R. Node: $L$. forsteri clade + L. ortizi clade
S. $L$. forsteri clade
T. $L$. ortizi clade
U. Node: L. robustus clade +
L. huacahuasicus clade
V. $L$. robustus clade
W. $L$. huacahuasicus clade

SVL $=77 \mathrm{~mm}$ ), possessing smooth, juxtaposed dorsals, high counts of scales around the midbody $(\leq 105)$, dorsals $(\leq 100)$ and ventrals $(\leq 105)$, presence of pores in the scales of the neck, venter, groin and tail, and the males generally have a yellow abdomen speckled with small dark spots. These species are distributed in north-western Argentina, south-western Bolivia and north-eastern Chile (Fig. 5). This clade is supported by three continuous characters, eight discrete characters and two coloration characters (Supporting Information, Table S1). This clade was recovered in all hypotheses, with the same composition of terminals and topology and, in most cases, was found as sister to the L. reichei clade.

\section{Liolaemus reichei Werner, 1907 clade}

This clade is composed of 15 terminals, of which five correspond to described species and ten correspond to populations of uncertain taxonomic status (Fig. 3). These are small-bodied lizards (maximal SVL $=65 \mathrm{~mm}$ ), with short tails in relationship to SVL, heads almost as wide as long, isognathus profiles, between 45 and 75 scales around the midbody, and between 50 and 90 smooth, juxtaposed dorsals. The clade is supported by five continuous characters, four discrete characters and four colour characters (Supporting Information, Table $\mathrm{S} 1)$. The $L$. reichei clade is recovered in all hypotheses, with the same composition and always divided into the same two subclades. One subclade includes four described species [Liolaemus audituvelatus Núñez \& Yáñez, 1983, Liolaemus poconchilensis Valladares, 2002, L. reichei Werner, 1907 and Liolaemus torresi (Núñez et al., 2003)] and two populations of uncertain taxonomic status, all of which are distributed in northwestern Chile (Fig. 3). The other subclade is composed of nine terminals, of which only Liolaemus insolitus Cei, 1982 has been described formally, evidencing the diversity awaiting description in this subclade. This clade is found in southern Peru, primarily in coastal zones (Fig. 4).

\section{Liolaemus jamesi clade}

This clade includes four described species [Liolaemus aymararum Veloso et al., 1982, Liolaemus hajeki Núñez, Pincheira-Donoso \& Garín, 2004, Liolaemus jamesi (Boulenger, 1891) and Liolaemus pachecoi Laurent, 1995] and a terminal representing a population of uncertain taxonomic status ( $L$. aff. aymararum). These lizards are characterized by their large size (maximal SVL $=100 \mathrm{~mm}$; except L. hajeki, maximal SVL $=72 \mathrm{~mm}$ ), bodies almost as wide as long, with large, juxtaposed dorsals, often with black skin visible between the scales, low numbers of scales around the midbody $($ mean $=45$; except $L$. hajeki, mean $=56$ ), ventral melanism present and conspicuous sexual dichromatism. The L. jamesi clade is found in north-eastern Chile and south-western Bolivia (Fig. 4) and is supported by one morphometric character, three coloration characters and 20 molecular characters (Supporting Information, Table S1). This clade was recovered in the majority of the hypotheses, but in the trees where $K=7-15$ this clade was integrated with the $L$. forsteri clade. The (L. hajeki $+L$. jamesi) and (L. aymararum (L. pachecoi + L. aff. aymararum)) relationship was recovered in all hypotheses obtained (Fig. 3).

\section{Liolaemus dorbignyi clade}

This clade includes L. dorbignyi Koslowski, 1898, Liolaemus huayra Abdala et al., 2008, Liolaemus aff. jamesi3, Demangel, 2016, Liolaemus inti Abdala et al., 2008, Liolaemus puritamensis Núñez \& Fox, 1989, Liolaemus scrocchii Quinteros et al., 2008, Liolaemus vulcanus Quinteros \& Abdala, 2011 and four terminals of uncertain taxonomic status: $L$. aff. huayra, $L$. aff. jamesi $1, L$. aff. jamesi 2 and $L$. aff. puritamensis (Fig. 3). These are large, saxicolous lizards, with maximal $\mathrm{SVL}=98 \mathrm{~mm}$, wide bodies, short tails in relationship to SVL, large, smooth to weakly keeled, juxtaposed to subimbricate dorsals, with exposed black skin and numerous heteronote granules between the scales of the dorsum and flanks, a large, dark spot on the dorsal 


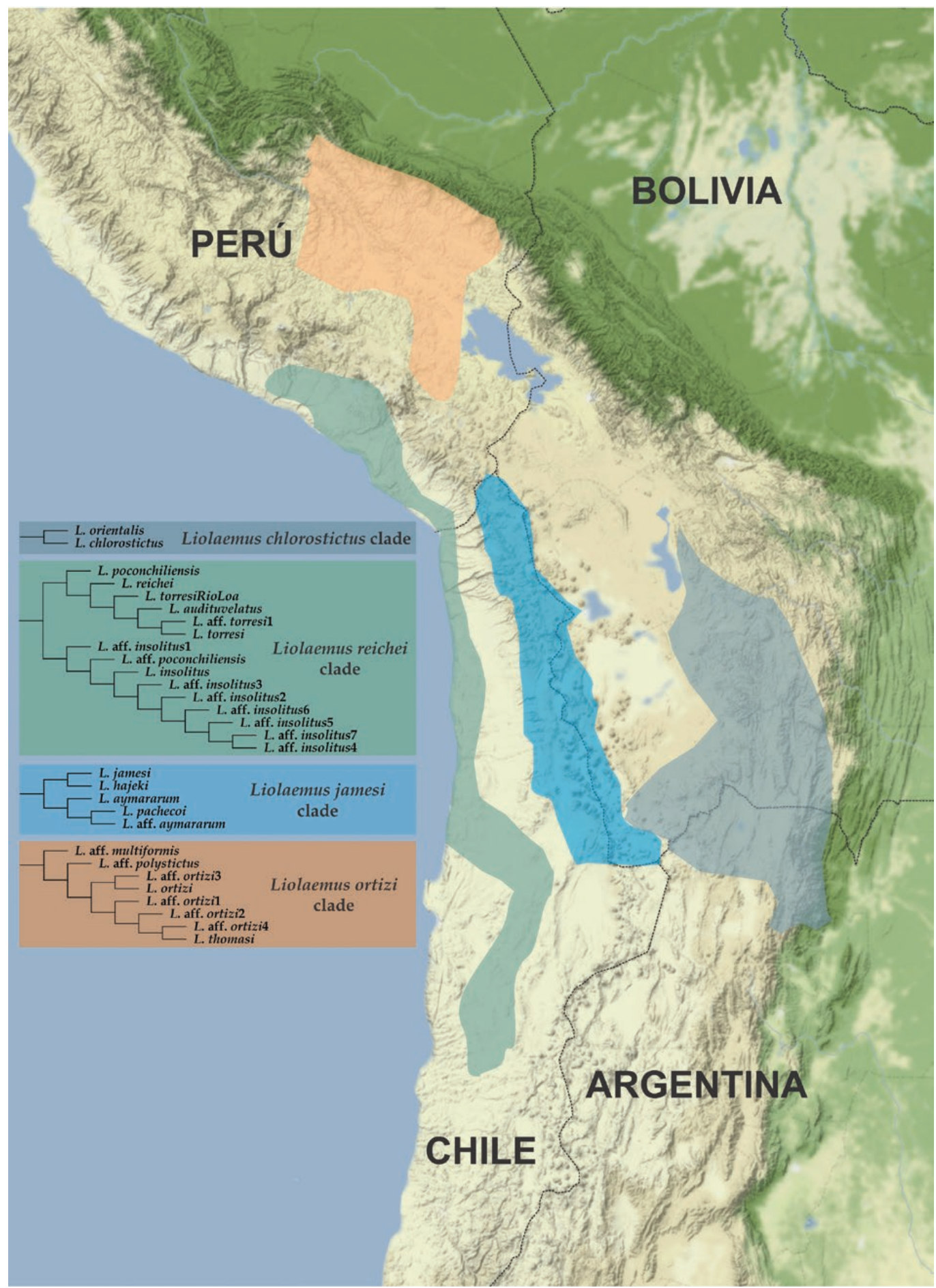

Figure 4. Map showing distribution of the taxa members of the Liolaemus chlorostictus, Liolaemus reichei, Liolaemus jamesi and Liolaemus ortizi clades.

surfaces of the head and neck, little evident sexual dichromatism in various species, and a ventral region with a dark reticulate pattern. The $L$. dorbignyi clade occurs in north-western Argentina, north-eastern
Chile, south-western Bolivia and extreme southeastern Peru (Fig. 6) and is supported by one continuous character and 11 coloration characters. This group was recovered in all of the hypotheses obtained. 


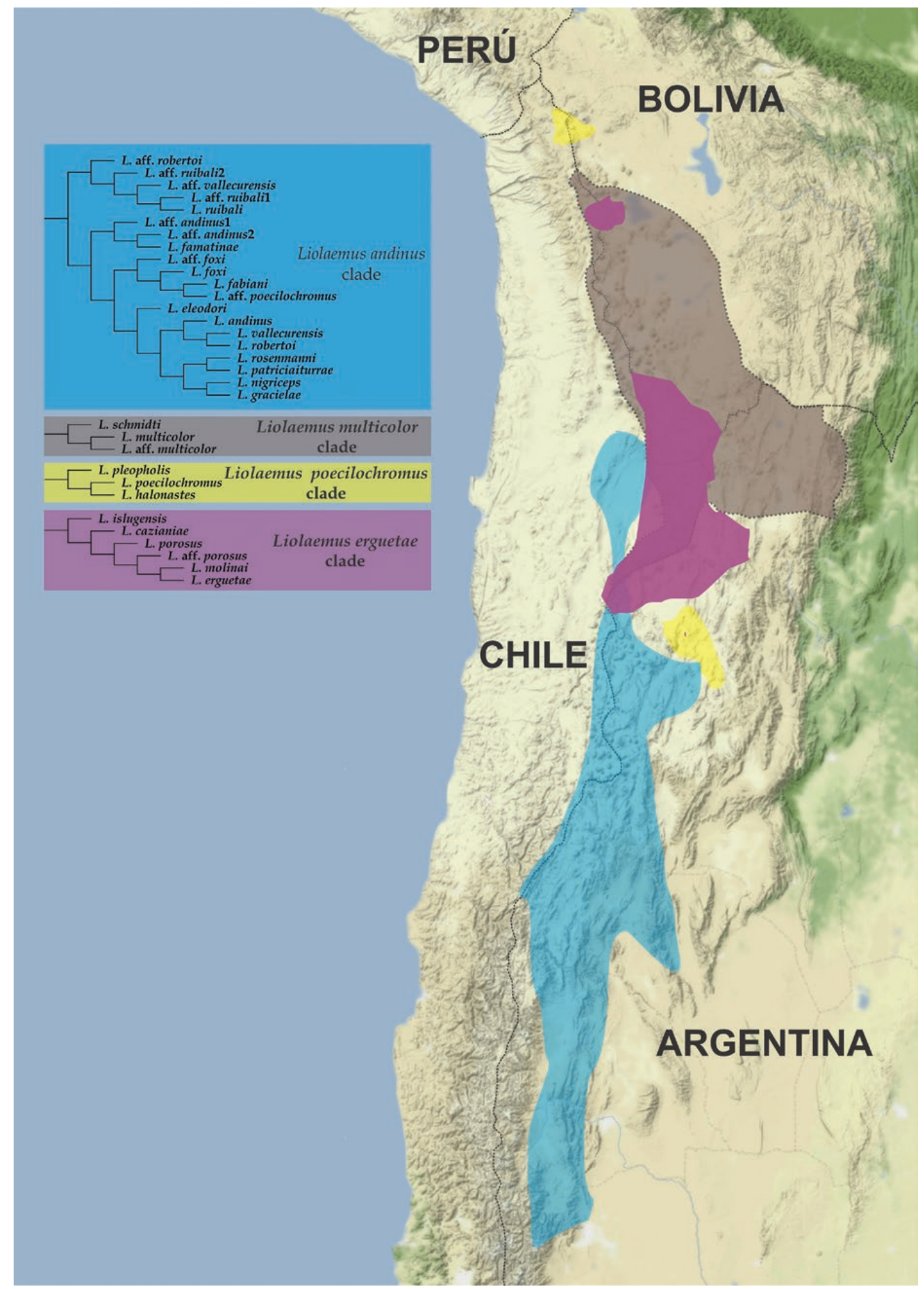

Figure 5. Map showing distribution of the taxa members of the Liolaemus andinus, Liolaemus multicolor, Liolaemus poecilochromus and Liolaemus erguetae clades.

Liolaemus forsteri clade

This clade includes three terminals: $L$. forsteri, $L$. aff. forsteri 1 and $L$. aff. forsteri2 (Fig. 3). They are large lizards (maximal SVL $=95 \mathrm{~mm}$ ), with weakly keeled subimbricate dorsal scales and large, red to yellow blotches on the dorsum of the torso. The $L$ forsteri clade is distributed in southern Peru and northern Andean Bolivia (Fig. 6) and is supported by three continuous 
characters, four discrete characters and three coloration characters (Supporting Information, Table S1). Half of the analyses recovered the following relationships: $(L$. aff. multiformis ( $L$. forsteri $(L$. aff. forsteri $1+L$. aff.forsteri 2$))$ ). This clade was placed as sister to either the $L$. ortizi clade ( $K=16-22)$ or the $L$. jamesi clade $(K=7-15)$.

\section{Liolaemus ortizi clade}

This clade is composed of eight terminals, of which only two correspond to described species: Liolaemus ortizi Laurent, 1982 and Liolaemus thomasi Laurent, 1998. All other terminals correspond to populations of uncertain taxonomic status (Fig. 3). This group of lizards as characterized by their medium size and low numbers of scales, not exceeding 65 around the midbody, 70 dorsals and 85 ventrals. Dorsal scales of the body and limbs are strongly keeled and imbricate. This clade is supported by two continuous characters, four lepidosis characters and one colour character. In hypotheses where $K=3-15$, the $L$. ortizi clade is recovered without $L$. aff. multiformis and related to $L$. huacahuasicus where $K=3-8$. In the remaining TEHs, the same composition and topology is recovered as in the proposed hypothesis. The $L$. ortizi group is distributed in high regions of central and southeastern Peru (Fig. 4).

\section{Liolaemus robustus clade}

This clade consists of (Liolaemus williamsi Laurent, 1992 + Liolaemus melanogaster Laurent, 1998) + (Liolaemus polystictus Laurent, $1992+$ Liolaemus robustus Laurent, 1992) (Fig. 3). They are medium to large lizards (maximal SVL $=80-95 \mathrm{~mm}$ ), with subimbricate smooth to weakly keeled dorsal scales on the body. The males are generally of a chestnut colour, with a tendency towards melanism of the pileus. The L. robustus clade is distributed in central Peru (Fig. 6) and is supported by three continuous characters, one discrete character and five molecular characters (Supporting Information, Table S1). The composition of this group was recovered in all hypotheses obtained, except where $K=3-8$, where it was united with the L. huacahuasicus clade.

\section{Liolaemus huacahuasicus clade}

This clade includes 14 terminals (Fig. 3), all mediumsized lizards (maximal SVL $=85 \mathrm{~mm}$ ) with triangular, imbricate, keeled dorsal body scales, with the dark scales being more strongly keeled than the lighter scales. Body colour in males varies between chestnut and yellow, and there are dark paravertebral blotches with light borders and a generally yellowish venter. This clade is supported by one discrete morphological character, four discrete coloration characters and eight molecular characters (Supporting Information, Table S1). The lizards of the L. huacahuasicus clade are distributed in the extra-Andean sierras of Argentina (L. montanus, L. aff. montanus, Liolaemus griseus Laurent, 1984, L. orko, L. huacahuasicus and Liolaemus pulcherrimus Laurent, 1982), Puna and high Amazonian slopes of Bolivia (L. signifer, $L$. fittkaui and $L$. aff. signifer2), Chilean Puna ( $L$. aff. signifer 1 ) and the Puna and western ranges of Peru (Liolaemus annectens Boulenger, 1901, L. aff. annectens, Liolaemus etheridgei Laurent, 1998, L. evaristoi Gutiérrez et al., 2018 and L. signifer) (Fig. 6). The composition of the L. huacahuasicus clade was recovered in all analyses except the hypotheses where $K=3-8$, in which $L$. annectens, $L$. evaristoi, $L$. signifer, $L$. etheridgei, $L$. aff. annectens and $L$. aff. signifer 1 formed a group separate from the rest of the L. huacahuasicus clade and sister to the L. robustus clade, whereas the monophyletic group formed by L. montanus, L. aff. montanus, L. griseus, L. fittkaui, L. orko, L. huacahuasicus, L. pulcherrimus and L. aff. signifer 2 were related to part of the $L$. ortizi clade.

\section{MIXED BAYESIAN HYPOTHESIS}

This hypothesis was highly congruent with that obtained with 'parsimony' (Fig. 7). The clades and groups recovered within the $L$. montanus group were the same, with changes in composition in only a few instances. The L. chlorostictus, L. multicolor, $L$. reichei, $L$. forsteri and $L$. robustus clades had the same species composition, with only some changes in the internal relationships (Fig. 7). The clade with the greatest differences with regard to the 'parsimony' hypothesis was the L. huacahuasicus clade, which included members of the $L$. andinus clade ( $L$. robertoi Pincheira-Donoso \& Nuñez, 2003, L. vallecurensis and $L$. aff. poecilochromus), the $L$. dorbignyi clade ( $L$. aff. jamesi3, L. aff. jamesi 1 and $L$. aff. jamesi2), the L. jamesi clade (L. aymararum) and the L. ortizi clade (L. aff. multiformis) (Fig. 7).

\section{MORPHOLOGY-BASED HYPOTHESIS (MH)}

In all runs performed with the morphology-only matrix, the L. montanus group was never recovered as monophyletic; instead, the outgroup species L. abaucan, L. inacayali, L. kingii, L. kolengh, L. pseudoanomalus, $L$. robertmertensi and $L$. tiranti were included within the L. montanus group, always as terminals of the $L$. ortizi group. Nevertheless, owing to the evidence for monophyly provided by the TEH and molecular hypotheses in the present study and by other authors (Schulte et al., 2000, 2013; Espinoza et al., 2004; Aguilar-Puntriano et al., 2018) and understanding that the outgroup and the characters 


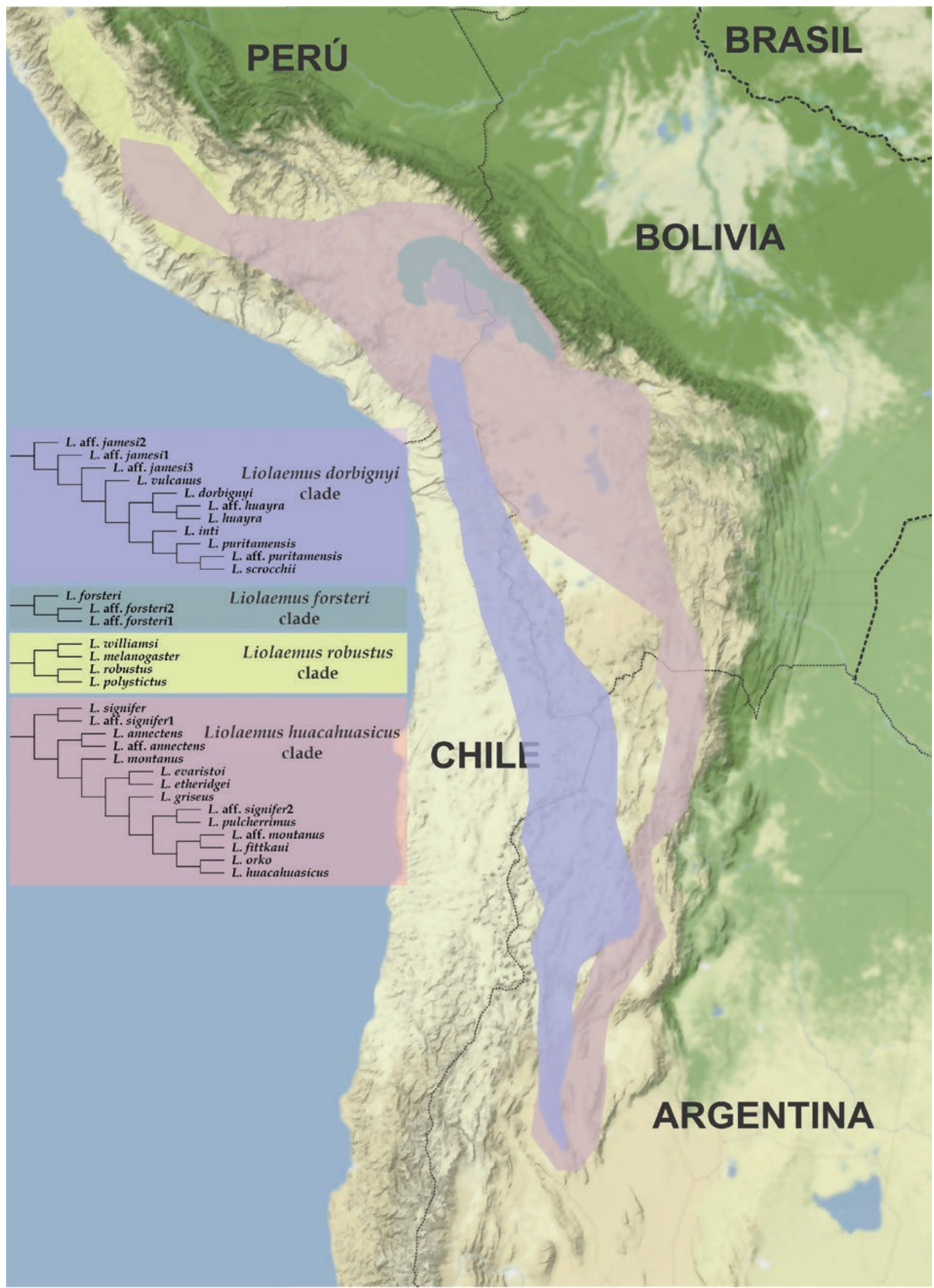

Figure 6. Map showing distribution of the taxa members of the Liolaemus dorbignyi, Liolaemus forsteri, Liolaemus robustus and Liolaemus huacahuasicus clades.

proposed to separated them are not sufficient to demonstrate monophyly, we have decided to present only the $\mathrm{MH}$ without the conflicting terminals under the assumption of a monophyletic L. montanus group.
Various hypotheses with different typologies and compositions were obtained for the clades within the $L$. montanus group, as a function of the $K$ values applied. Based on the criteria proposed by Mirande (2009), we 


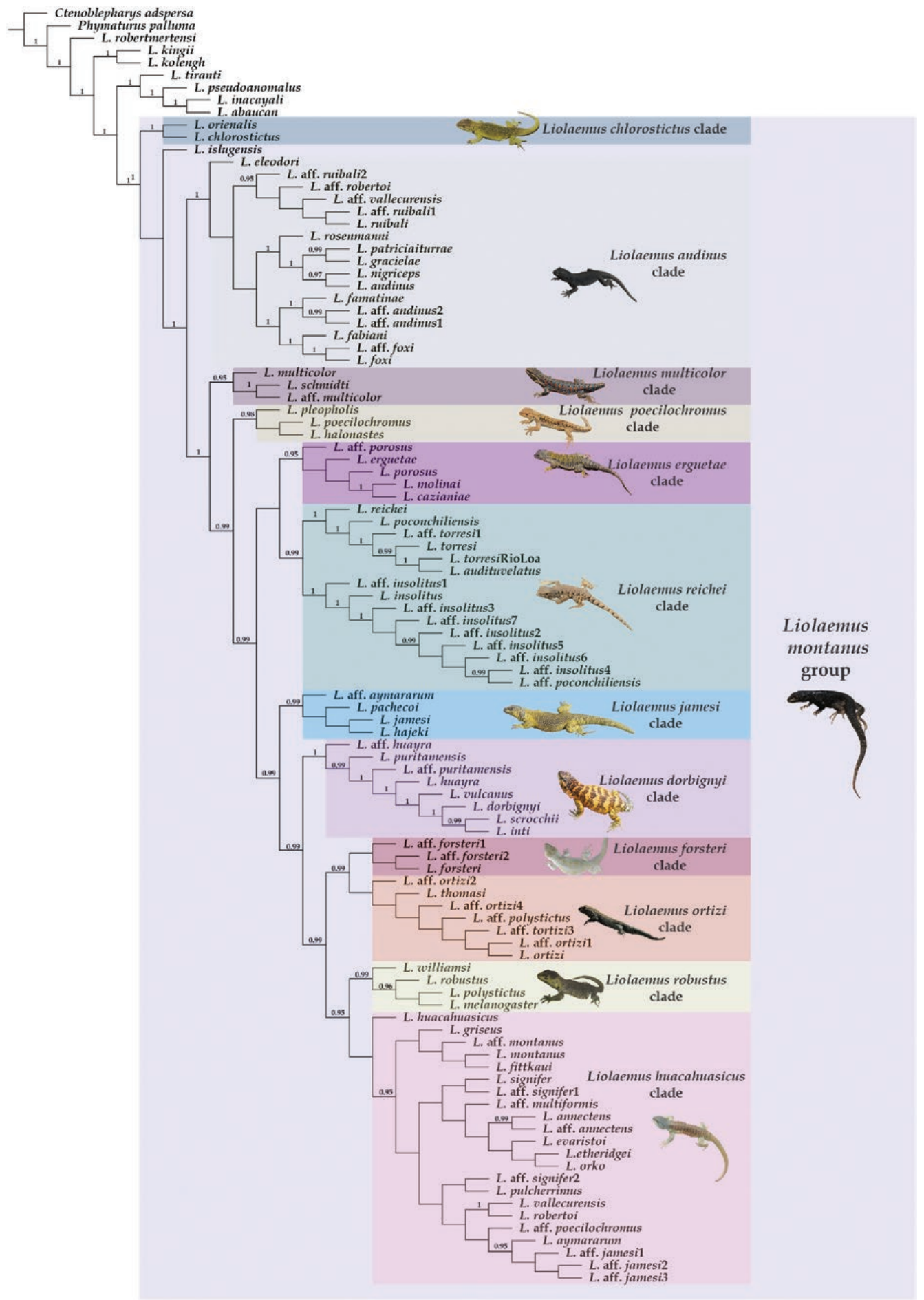

Figure 7. Mixed Bayesian hypothesis.

selected the most stable phylogenetic hypothesis, in which $K=14$, as our proposed hypothesis (Fig. 8). This same hypothesis was also recovered with $K=12-16$. Thus, the proposed hypothesis was highly congruent with the hypothesis obtained when $K=7-11$, recovering the same groups, albeit with some differences in their relationships and composition. In the proposed $\mathrm{MH}$, the $L$. montanus group was supported by 31 characters, of which nine were continuous, 11 were lepidosis characters and the remaining 11 were miscellaneous. 


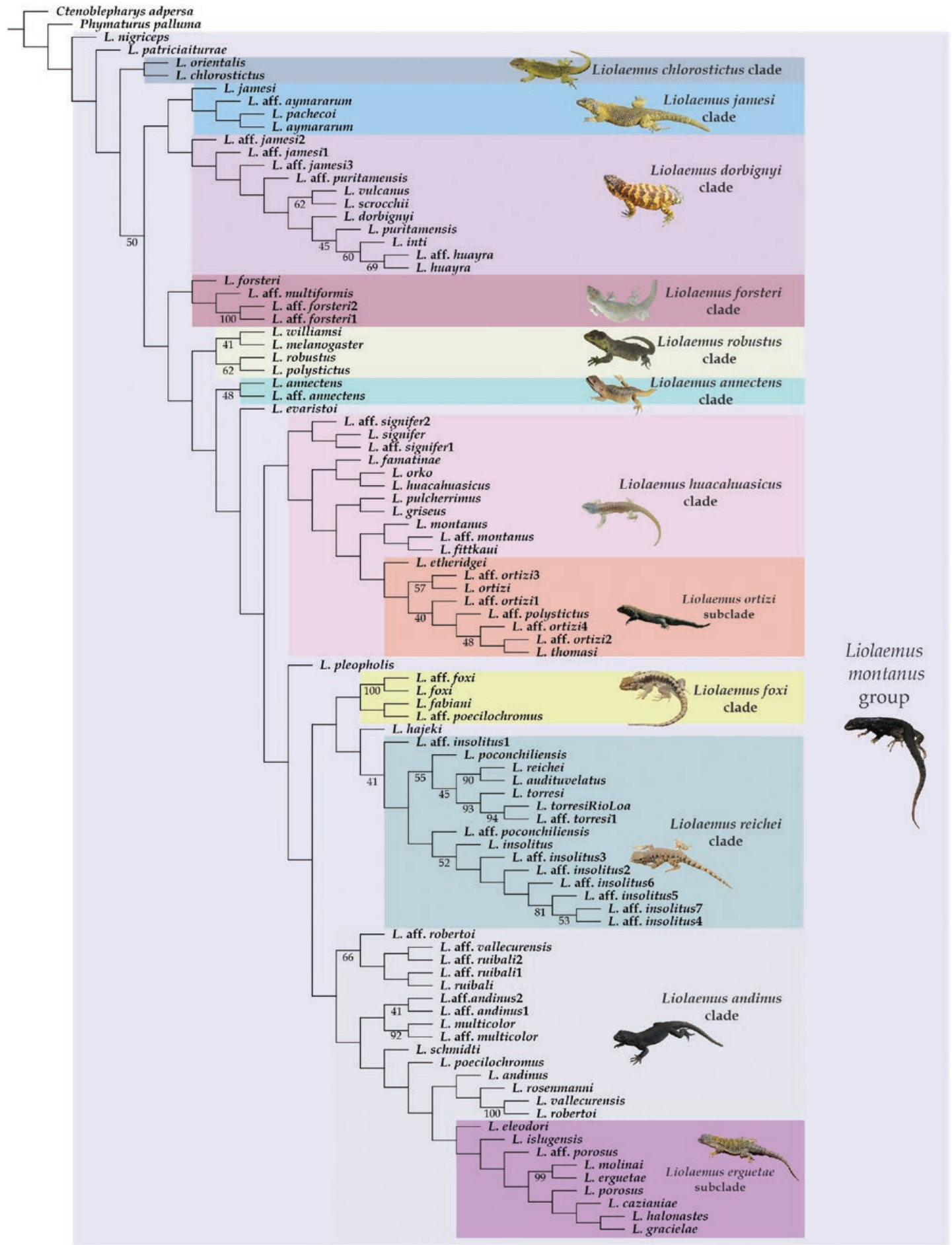

Figure 8. Topology recovered with the morphological hypothesis under parsimony $(K=14)$. Numbers below branches correspond to symmetric resampling.

In the proposed $\mathrm{MH}$, ten clades were recovered, of which eight were congruent with those proposed by the TEH (Fig. 3). The species L. nigriceps and L. patriciaiturrae were placed basally and outside of the $L$. andinus clade, as also occurred in the TEH. The following clades were recovered (Fig. 8): (L. nigriceps (L. patriciaiturrae (L. chlorostictus clade (L. jamesi clade $+L$. dorbignyi clade $)+(L$. forsteri clade 
(L. robustus clade (L. annectens clade (L. evaristoi (L. huacahuasicus clade (L. pleopholis ( $L$. foxi clade $(L$. hajeki + L. reichei clade $)+L$. andinus clade)))))))))).

This tree recovered two clades not recovered by the TEH: the $L$. foxi clade, present in the TEH as a subclade of the $L$. andinus clade, and the $L$. annectens clade, present as a subclade of the L. huacahuasicus clade in the TEH. Also, all members of the TEH $L$. multicolor clade were integrated in the $L$. andinus clade, as was the TEH $L$. erguetae clade, which was recovered as a subclade including $L$. halonastes (Fig. 8). The $L$. poecilocromus clade was not recovered in the $\mathrm{MH}$, and some of its members (L. poecilochromus and $L$. halonastes) were included in the $\mathrm{MH} L$. andinus clade. The $L$. ortizi clade was recovered but as a subclade of the L. huacahuasicus clade. The L . chlorostictus, $L$. dorbignyi, L. robustus and L. reichei clades were recovered in the $\mathrm{MH}$ with the same composition as in the TEH. The $\mathrm{MH}$ did not recover L. hajeki in the $L$. jamesi clade, but instead placed it rather distantly as sister to the $L$. reichei clade. The $L$. forsteri clade included $L$. aff. multiformis, which the TEH placed in the $L$. ortizi clade, but this the relationship found by the MH was congruent with various hypotheses obtained with different $K$ values in the TEH. The MH $L$. huacahuasicus clade incorporated species of the TEH $L$. ortizi clade and did not recover the species $L$. annectens and $L$. aff. annectens, which formed a separate clade. The MH $L$. foxi clade was formed by $L$. foxi, $L$. fabiani, $L$. aff. foxi and $L$. aff. poecilochromus and was placed as sister to the $L$. hajeki $+L$. reichei clade. The MH L. reichei clade presented minor differences from the clade recovered by the TEH, because the terminal $L$. aff. insolitus 1 was here located basally to the two subclades otherwise recovered by the TEH. The MH $L$. andinus presented various congruent relationships with the TEH, but placed the $L$. erguetae clade as a subclade within the $L$. andinus clade.

\section{MOLECULAR HYPOTHESIS}

In order to obtain a molecular evidence-only hypothesis, we generated an agreement subtree (Fig. 9), which discarded conflictive terminal taxa (without sequence), resulting in a highly unresolved topology that might be attributable to the high percentage of missing data in some terminal taxa. The agreement subtree recovered the $L$. montanus group as monophyletic, but formed by only nine of the 12 monophyletic groups recovered by the TEH (Figs 3, 9). The overall topology was similar to that recovered by the TEH and $\mathrm{MH}$, but with fewer taxa owing to the absence of species without molecular data.

The L. chlorostictus clade was not recovered as such, because $L$. orientalis was one of the species excluded from the analysis (Fig. 9).
The $L$. andinus clade was recovered as a group formed by 15 terminal taxa, five fewer than in the $\mathrm{TEH}$. The differences between the terminals differed slightly from those recovered by the TEH (Fig. 9).

The $L$. multicolor clade was covered with the same composition and internal relationships as in the TEH (Fig. 9).

The L. poecilochromus clade was recovered with a similar composition to that of the TEH, but not including $L$. pleopholis, which was excluded from the analysis (Fig. 9).

The $L$. erguetae clade was recovered with three terminal taxa (out of the six that were included in the $\mathrm{TEH})$. The other three remaining taxa were excluded from the analysis (Fig. 9).

An $L$. reichei clade with four terminal taxa was recovered. Most of the terminal taxa that formed part of this group in the TEH were excluded from the analysis (Fig. 9).

The $L$.jamesi clade was recovered with three terminal taxa. Liolaemus pachecoi and $L$. aff aymararum, which were part of the TEH, were excluded from the analysis (Fig. 9).

The $L$. dorbignyi clade was recovered with the same relationships as in the TEH. However, only six of the 11 terminals of the TEH were included in the molecular matrix (Fig. 9).

The L. huacahuasicus clade was recovered, but only two terminal taxa were included out of the 14 included in the TEH matrix (Fig. 9).

\section{DISCUSSION}

The L. montanus group (L. montanus series sensu Schulte et al., 2000), which contains 64 recognized species, is one of the most diverse groups within the Liolaemus genus (Abdala \& Quinteros, 2014; Gutiérrez et al., 2018; Aguilar et al., 2019), and our TEH recovered an additional 37 candidate species. Despite the importance of this group within Liolaemus, the phylogenetic relationships had not been studied in depth. Most of the previous studies including this group were broader phylogenies of the genus (Schulte et al., 2000; Espinoza et al., 2004; Avila et al., 2006; Pyron et al., 2013; Schulte, 2013; Zheng \& Wiens, 2016; Esquerré et al., 2019) or based on a particular internal group (Valladares et al., 2002; Olave et al., 2014; Aguilar et al., 2017). Espinoza et al. (2004) studied the evolution of herbivory in Liolaemidae and obtained a phylogenetic tree based on 24 morphological characters (plus ND2 and $12 \mathrm{~S}$ sequences) but included only eight species (11.9\%) of the group. Esquerré et al. (2019) studied the evolution of the reproductive modes within Liolaemidae, following a phylogenetic approach using mitochondrial (12S, Cytb, ND2 and 


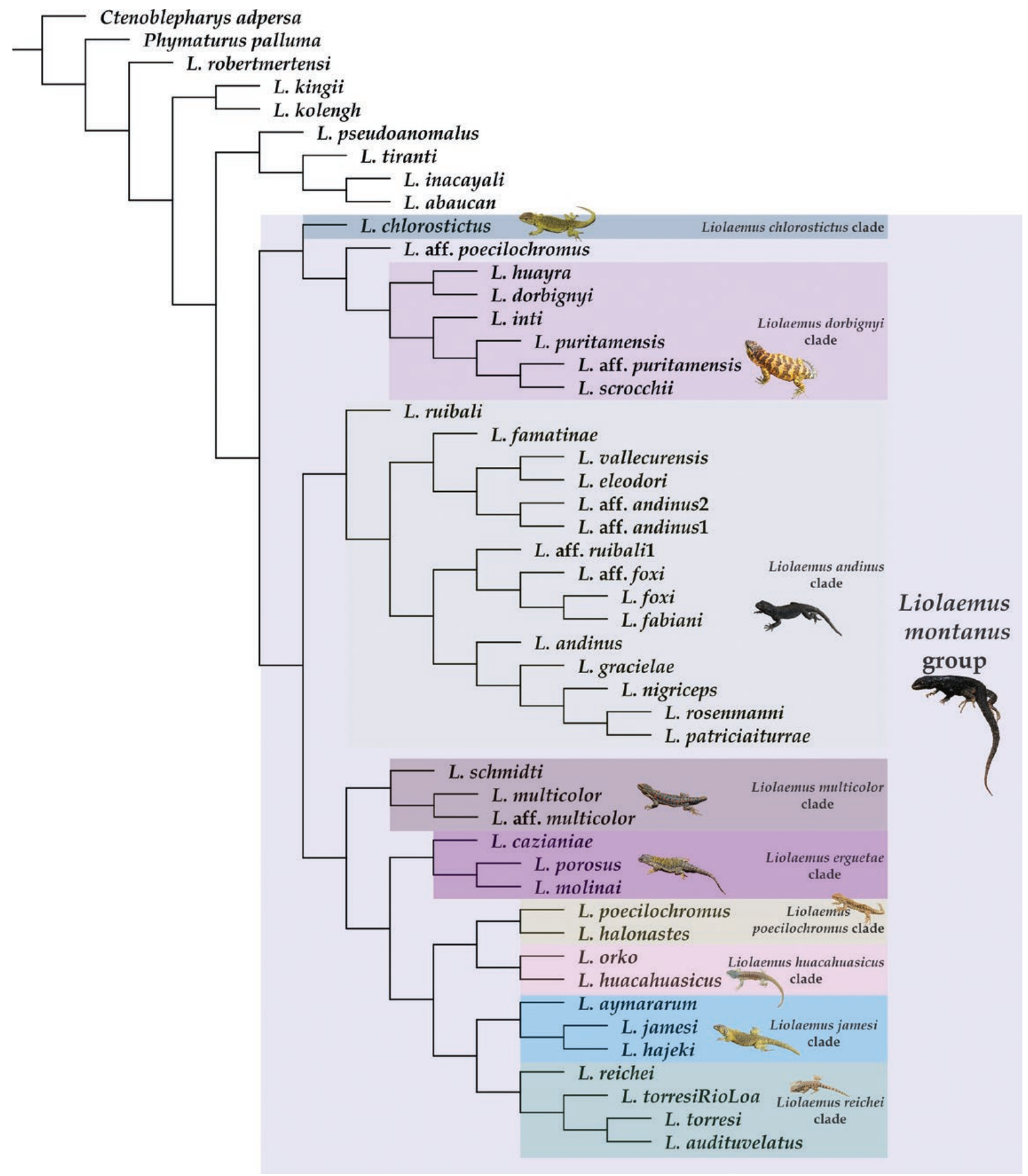

Figure 9. Molecular analysis tree.

ND4) and nuclear (BID, EXPH5, KIF24, MXRA5, PLRL and $P N N$ ) loci. The broad taxonomic coverage of their phylogenetic hypotheses is noteworthy and recovered a well-supported L. montanus group, but their analyses included only $26(40.6 \%)$ of the 64 recognized species of the group.
A recent work examining the evolution of head shape among species in the L. montanus group presented molecular-based phylogenetic estimates based on two mitochondrial $(C y t b, 12 \mathrm{~S})$ and five nuclear (CMOS, EXPH5, KIF24, MXRA5 and PRLR) genes (Aguilar-Puntriano et al., 2018). Although it was 
the richest-sampled phylogeny for the L. montanus group to date, including 57 terminals, 14 of these were identified as candidate species and one was a 'cf.', resulting in a phylogeny including 43 terminal taxa assigned to species $(67.1 \%)$ of the 64 recognized species.

To date, no other phylogeny for the species of the L. montanus group has included both exhaustive morphological data and molecular evidence. Also, by including 103 terminals, 56 (87.5\%) of which belong to recognized species, with the remaining 37 being candidate species, our study presents a more comprehensive phylogeny of the L. montanus group by including a considerable number of morphological traits and two or three times more terminal taxa than previous studies.

\section{DIFFERENCES BETWEEN OUR HYPOTHESES}

The cladistic analyses performed here resulted in three phylogenetic hypotheses (Fig. 10) based on the three different datasets: (1) morphological characters only; (2) molecular characters only; and (3) the total evidence dataset, including both morphological characters and gene sequences. Most of the previous phylogenies of the L. montanus group were based on molecular data only (Schulte et al., 2000; Espinoza et al., 2004; Fontanella et al., 2012; Olave et al., 2014; Aguilar-Putriano et al., 2018; Esquerré et al., 2019). However, our molecular-based phylogeny obtained a hypothesis with a subsampled number of taxa, because of the unavailability of sequences for all terminals. Nevertheless, our morphological-only phylogeny for the L. montanus group is the first to include an exhaustive suite of morphological character states, and we consider it necessary to obtain a topology based only on this dataset for diagnostic purposes. Although the phyologeny of Espinoza et al. (2004) included some morphological characters, all of them were synapomorphies of Ctenoblepharys, Liolaemus and Phymaturus, and although useful to diagnose the main groups inside these genera, they were not intended to discriminate between taxonomic groups inside the L. montanus group.

The L. montanus group was recovered as monophyletic in all the hypotheses we obtained. However, the relationships between the clades and subclades within the L. montanus group differed among the three topologies recovered. Despite the incongruence found, Subtree Pruning and Regrafting distances between the three topologies (TEH vs. morphology $=0.6$; TEH vs. molecular $=0.82 ;$ and morphology vs. molecular $=0.7$ ) showed some congruence between the three topologies recovered (Fig. 10). Despite the lower number of terminal taxa included in the molecular-based phylogeny, there was a high level of congruence between that topology and the other two. The TEH recovered 12 internal clades, of which nine were recovered in the molecular-based phylogeny and ten in the morphologybased phylogeny. From those previous ten recovered in the morphology-based phylogeny, two clades were nested inside other clades, namely the $L$. erguetae and $L$. ortizi subclades (nested within the L. andinus and L. hucahuasicus clades, respectively). Additionally, the morphology-based topology recovered two more clades that were not recovered in the TEH, the $L$. annectens and $L$. foxi clades (Fig. 10). Species of those clades were members of the $L$. huacahuasicus and L. andinus clades, respectively, in the TEH.

Although molecular datasets have been widely used in phylogenetic reconstruction since the $1990 \mathrm{~s}$, the use of morphological data has been rejected by some
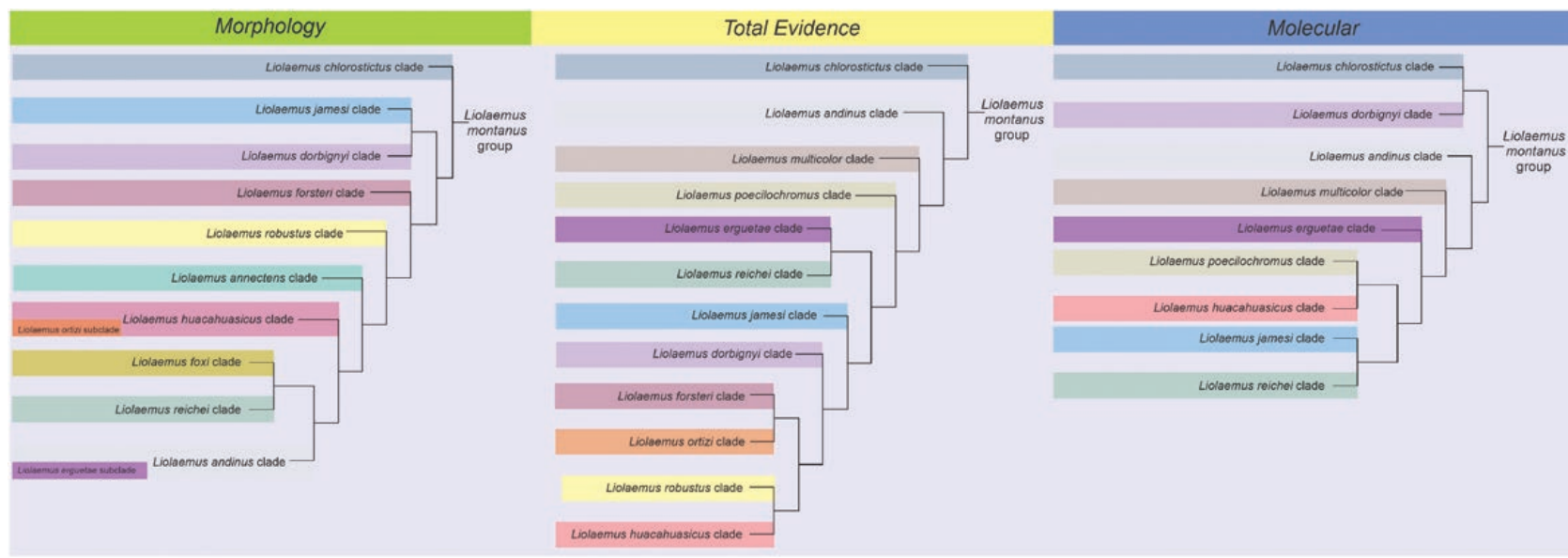

Figure 10. Summarized tree topologies showing the main monophyletic groups recovered under the total evidence, morphological and molecular hypotheses. Shading colours represent the same monophyletic group in each hypothesis. 
researchers, who argue that morphology carries a high level of homoplasy (Alvarez et al., 1999; Mueller et al., 2004; Escobar García et al., 2009; Mott \& Vieites, 2009). But there is also evidence of homoplasious molecular data (Engstrom et al., 2004; Castoe et al., 2009; Jarvis et al., 2014). Nevertheless, the use of morphological character states has remained widespread for the Liolaemidae (Lobo, 2001, 2005; Lobo \& Quinteros, 2005; Abdala, 2007; Quinteros, 2013; Abdala \& Juárez Heredia, 2013). Continuous characters analysed as such were used in many different studies (e.g. Abdala, 2007; Quinteros, 2013; Álvarez et al.,2017; Barrionuevo, 2017; Bardin et al., 2017; Portelli \& Quinteros, 2018). Moreover, the inclusion of continuous morphological characters reinforces our hypothesis, because many of them are recovered as synapomorphies in the total evidence analysis.

\section{DIFFERENCES FROM OTHER PHENETIC AND PHYLOGENETIC HYPOTHESES}

As noted previously, many early hypotheses of relationships between species of the genus Liolaemus have been based on phenetic similarity [e.g. the species groups of Cei (1993) and Pincheira-Donoso \& Núñez (2005)], not phylogenetic analyses based on the evolution of character states. Table 1 compares our subgroup-level clades against phenetic species groups proposed by previous authors for species of the L. montanus group.

Given that the most comprehensive recent phylogenetic hypothesis for the L. montanus group is that of Aguilar-Puntriano et al. (2018), our discussion focuses on their findings. Although the hypothesis of Esquerré et al. (2019) includes 26 of the L. montanus group, we are aware of some difficulties with the species names assigned to certain terminals owing to the reliance upon data obtained from GenBank without rigorous review of taxonomic identifications. Also, the work of Esquerré et al. (2019) was not focused on the L. montanus group. For these reasons, we do not comment further on their findings.

Our TEH recovered the species pair L. chlorostictus and $L$. orientalis as basal to remainder of the $L$. montanus group. Liolaemus chlorostictus was described as a subspecies of $L$. orientalis by Laurent (1991) and elevated to a full species by Abdala et al. (2008); therefore, the close relationship between these two species was expected. The basal position of this clade within the $L$. montanus group is congruent with most previous estimates (Valladares et al., 2002; Espinoza et al., 2004; Pyron et al., 2013; Zheng $\&$ Wiens, 2016; Esquerré et al., 2019), all of which used the same molecular sample (GenBank accession AF099247), which corresponds to a nearly topotypic $L$. chlorostictus (although it has been identified as L. orientalis by most authors and GenBank). However, Schulte et al. (2000) recovered this specimen as basal to the clade including L. dorbignyi, L. poecilochromus, L. multicolor and ' $L$. andinus-Jujuy', which was sister to a clade consisting of $L$. ruibali, ' $L$. andinus-La Rioja' and $L$. famantinae. Based on two specimens collected in the Tarija Department of Bolivia, Aguilar-Puntriano et al. (2018), recovered $L$. orientalis as a member of a clade including L. multicolor, L. islugensis, L. cf. schmidti, L. pleopholis and three candidate species. Morphologically, L. orientalis is dissimilar to all of the recognized species of that clade in terms of pholidosis and coloration. Furthermore, they recovered L. chlorostictus (based on a topotypic specimen not included in GenBank) as sister to their Liolaemus sp. 3 (from the Bolivian Altiplano and Andes) within a larger clade including $L$. signifer, $L$. forsteri, $L$. annectens, L. etheridgei and various candidate species, a result not expected based on morphology or Laurent's original concept of $L$. chlorostictus. Unfortunately, the molecular data available for $L$. orientalis is limited to that reported by Aguilar-Puntriano et al. (2018). Additional geographical sampling of $L$. orientalis genes might clarify its relationships. If the hypothesis of Aguilar-Puntriano et al. (2018) is correct, the position of $L$. orientalis within what we could consider the $L$. multicolor group represents either a remarkable case of morphological convergence with members of other species groups or the conservation of a plesiomorphic large-scaled, drabcoloured phenotype within a group of the species that is otherwise characterized by more numerous and smaller dorsal scales and bright colours in males.

Liolaemus andinus Koslowsky, 1895 has a rather contentious taxonomic history owing to the loss of the type series and its vague type locality. However, it has been the prototypical species for the phenetic species group of $L$. montanus group species with numerous, small, juxtaposed dorsal scales and relatively low tail/SVL ratios. Owing to the non-existence of type material and the uncertainties of the type locality, the use of the name $L$. andinus in the literature postLaurent (1982) must thus be considered provisional in the absence of the designation of a neotype and restriction of the type locality. We note that our assignment of material to $L$. andinus is based on extensive fieldwork and collections in the Catamarca Province and adjacent Chile. The $L$. andinus group of Cei (1986) included L. andinus, L. multicolor and $L$. poecilochromus and was based on the presence of smooth and juxtaposed dorsal scales, absence of cephalic melanism and marked sexual dimorphism. Our hypotheses recover each of these species in their own unique species groups within the L. montanus group. Lobo et al. (2010a) included 23 species in their L. andinus group based on two character states they identified as synapomorphies: 'between 80-110 scales around midbody' and 'the presence of a particular sexual dichromatism'. However, not all the species 
included in the L. andinus group of Lobo et al. (2010a) are recovered as members of our $L$. andinus clade. Of the 23 species included by Lobo et al. (2010a), four of them (L. griseus, L. huacahuasicus, L. pulcherrimus and $L$. orko) are recovered in our $L$. huacahuasicus clade. Lobo et al. (2010a) included L. poconchilensis in their $L$. andinus group, whereas our phylogenetic hypotheses place $L$. poconchilensis as a member of the L. reichei clade. Nevertheless, Lobo et al. (2010a) mention that the phylogenetic position of these five species inside the $L$. andinus group is controversial, because the scale counts might be highly variable in comparison with the other members in the group.

The presence of smooth dorsal scales and the absence of cephalic melanism were used by Cei (1986) to define his $L$. ruibali group, including L. duellmani, L. eleodori, L. famatinae and L. ruibali. Cei (1986) also envisioned a close relationship between the $L$. ruibali group and L. andinus. Our results support this conclusion, because most members of Cei's $L$. ruibali group were recovered nested within the L. andinus clade (Fig. 3). However, the position of $L$. duellmani remains unknown, because we could not access specimens of this taxon for our analyses. The close relationship between $L$. andinus, L. fabiani, L. famatinae and L. ruibali obtained in the present study was previously recovered by Valladares et al. (2002). Nevertheless, L. fabiani was recovered as the sister taxon of $L$. audituvelatus by Valladares et al. (2002) using only molecular evidence. In contrast, we recovered $L$. audituvelatus as a member of the L. reichei clade (see below, in the paragraph on $\mathrm{L}$. reichei). The species included in the $L$. ruibali group proposed by Pincheira-Donoso \& Núñez (2005) were recovered nested in our $L$. andinus group. PincheiraDonoso \& Núñez (2005) applied groups of Cei (1986, 1993) and added the Chilean L. patriciaiturrae, $L$. robertoi and $L$. rosenmanni to the $L$. ruibali group. In the present study, we recovered those all those species nested within our $L$. andinus clade. PincheiraDonoso (2002) also assigned L. nigriceps to his $L$. ruibali group, a species we recovered as a member of our L. andinus group.

Aguilar-Puntriano et al. (2018) recovered the clade $(((((L$. patriciaiturrae + L. nigriceps $)(L$. rosenmanni $(L$. gracielae + L. vallecurensis $)) L$. foxi + $L$. audituvelatus) $L$. andinus $+L$. famatinae) $L$. ruibali), whose content is consistent with our $L$. andinus clade, with the exception of $L$. audituvelatus, which we recovered in our $L$. reichei clade.

The species included in our L. multicolor clade were previously proposed as members of the $L$. andinus group (Cei, 1993; Lobo et al., 2010a) or, in the case of $L$. schmidti, considered a synonym of $L$. andinus (Pincheira-Donoso \& Núñez, 2005). The sample identified as L. andinus AF099251 by Valladares et al. (2002) corresponded to our L . aff. multicolor, and the relationships for this taxon recovered here were similar to theirs. As noted above, Aguilar-Puntriano et al. (2018) recovered L. cf. schmidti, L. multicolor and other terminal taxa in a clade also including $L$. islugensis, $L$. orientalis and L. pleopholis plus some unnamed terminals. As discussed above, we recovered $L$. orientalis as sister to L. chlorostictus, which were placed together as basal within the L. montanus group. Other authors have recovered L. multicolor and L. poecilochromus as members of the same clade (Valladares et al., 2002; Espinoza et al., 2004; Esquerré et al., 2019) or even as sister taxa (Schulte et al., 2000). However, we recovered $L$. poecilochromus as a member of its own species group that also included L. halonastes and L. pleopholis; a clade supported by five continuous characters and six discrete characters related to coloration (Supporting Information, Table S1).

Our L. erguetae clade was composed of species with smaller, more numerous dorsal scales and marked sexual dichromatism, including $L$. islugensis, L. cazianiae, L. porosus, L. molinai and L. erguetae. Although Aguilar-Puntriano et al. (2018) recovered $L$. cazianiae and $L$. porosus as sister taxa, they did not find these to be closely related to $L$. islugensis (and did not include L. erguetae or L. molinai). Instead, they placed L. islugensis as sister to L. pleopholis within their clade including $L$. multicolor. Although $L$. islugensis is phenetically rather similar to L. multicolor, our TEH recovered it as the basal member of the L. erguetae clade, supported by 13 characters (Supporting Information, Table S1), as was also recovered by our morphology-only hypothesis (Fig. 8). The remaining species of the L. erguetae clade were supported by 23 morphological characters, including a high number of scales around the midbody, a high number of dorsal scales between the occiput and thighs, a high number of ventrals, males having dark coloration on the pileus, yellow pigmentation of the dorsal surface of the forefeet and hindfeet in both males and females, males with yellow pigmentation of the throat and belly, and dark spots in the centre of the belly and pygal region.

The TEH recovered the $L$. erguetae clade as sister to the $L$. reichei clade based on 15 characters (ten morphological and five molecular), including pores on the base of the tail, number of scale organs in the post rostral scale, number of subdigital lamellae of fourth finger, ratio between trunk width and trunk length, ratio between length of fourth toe and SVL, and dorsal coloration of the forefeet and hindfeet. However, this relationship was not recovered by either the morphology-only or the molecular-only hypothesis.

Our L. reichei group included some of the species formerly included in the invalid generic names Ctenoblepharys and Phrynosaura. In 1891, Steindachner (1891) described Ctenoblepharys stolzmanni, a species erroneously placed in the 
genus erected for Ctenoblepharys adspersa Tschudi, 1845 and unjustifiably emended by Boulenger (1891) when he described Ctenoblepharys jamesi. Eight years later, Werner (1907) described the genus Phrynosaura and its sole species, Phrynosaura reichei. Subsequently, other species were described or reassigned to this genus, including Phrynosaura marmoratus and Phrynosaura werneri (currently $L$. pseudoanomalus and L. anomalus, respectively), Phrynosaura audituvelatus (= L. audituvelatus) and C. stolzmanni (= L. stolzmanni). Etheridge (1995) synonymized Phrynosaura with Liolaemus and left Ctenoblepharys Tschudi, 1845 as a monotypic genus. However, Núñez \& Veloso (2001) described Phrynosaura audituvelata (= L. audituvelatus), and Núñez et al. (2003) described Phrynosaura manueli and Phrynosaura torresi (currently, L. manueli and L. torresi). Pincheira-Donoso \& Núñez (2005) used Phrynosaura to include the taxa mentioned above and excluded them from the monograph on the Chilean species of Liolaemus. Núñez et al. (2003) mentioned that the species of the genus Phrynosaura show a tibial process, a character state shared by all members of the L. montanus group (Etheridge, 1995). Breaking with the tradition of some Chiliean workers, PincheiraDonoso et al. (2008) included the species previously encompassed in Phrynosaura in the L. reichei group (formed by L. audituvelatus, L. erroneous, L. manueli, $L$. poconchilensis, $L$. reichei and $L$. torresi). In the present study, we recovered an $L$. reichei clade formed by two monophyletic groups: one including $L$. insolitus and eight unnamed terminal taxa and the other resembling the $L$. reichei group of Pincheira-Donoso et al. (2008). Pincheira-Donoso et al. (2008), however, included $L$. insolitus in their L. montanus clade. Aguilar-Puntriano et al. (2018) explicitly investigated the phylogenetic relationships of the L. montanus group species, and their phylogenetic hypothesis distributed species with this morphological syndrome across three clades within the $L$. montanus group and rejected the hypothesis that the 'phrynosauroid' species form a monophyletic group, in contrast to our TEH.

Our TEH recovered $L$. jamesi and $L$. dorbignyi as belonging to their own eponymous clades, which were distinguished morphologically by the presence of spots on the gular region, dorsal region of tail with the same colour pattern as the dorsum, tip of ventral region of tail the same colour as the central belly in the L. jamesi group, and dark skin on the dorsum, dark skin on the dorsum of forelimbs, black markings on the chest, belly and pygal region grille-shaped or reticulate, dark markings on the ventral region of the tail grill-shaped or reticulate, and dots on the scapular region in the L. dorbignyi group. Aguilar-Puntriano et al. (2018) recovered similar clades, but with some differences in their relationships to other clades. First, they recovered the phrynosauroid L. stolzmanni as sister to ((L. hajeki + L. jamesi) (L. aymararum + L. pachecoi $))$. Second, their $((L$. vulcanus + L. dorbignyi $)(L$. inti $+L$. scrocchi $))$ clade was sister to $L$. fittkaui, and those five species were sister to (L. huacahuasicus (L. cazianiae $+L$. porosus)). We recovered $L$. fittkaui as a member of our $L$. huacahuasicus clade and placed $L$. cazianiae and $L$. porosus in our $L$. erguetae clade (L. erguetae was not included in the analysis by Aguilar-Puntriano et al., 2018).

Liolaemus puritamensis was described from Chilean material by Núñez \& Fox (1989), but Núñez \& Jaksic (1992) soon synonymized it with the Argentine L. dorbignyi. Subsequently, Pincheira-Donoso \& Núñez (2005) resurrected L. puritamensis as a valid species, but they compared it against specimens from Salta now assigned to L. scrocchii (Quinteros et al., 2008), not the true $L$. dorbignyi from Catamarca. In the present study, we recovered $L$. puritamensis as a member of the $L$. dorbignyi clade but clearly distinct from all described species of the group. Moreover, we identified the population assigned to L. puritamensis in Argentina as a candidate species, which we will describe in a future paper.

The remaining four clades (L. forsteri, $L$. ortizi, $L$. robustus and $L$. huacahuasicus clades) formed a larger clade sister to the $L$. dorbignyi clade and included $L$. signifer, $L$. annectens and related species from Peru, Bolivia and Argentina described almost entirely by Laurent in the 1980 s and 1990 s. Although we recovered the $L$. forsteri clade as sister to our L. ortizi clade, Aguilar-Puntriano et al. (2018) placed $L$. forsteri either as sister to $L$. signifer or as the basal member of larger clade sister to L. ortizi + $L$. thomasi and including L. annectens, L. chlorostictus, L. etheridgei, L. signifer, the members of our L. robustus and several candidate species. Our TEH recovered $L$. annectens, $L$. etheridgei and L. signifer within the L. huacahuasicus clade. These taxa were recovered as closely related by Aguilar-Puntriano et al. (2018), but these authors recovered $L$. huacahuasicus as sister to $L$. cazianiae and $L$. porosus, which collectively were sister to species recovered in our $L$. dorbignyi clade. Overall, our hypotheses for these groups were similar to those of Aguilar-Puntriano et al. (2018), but those authors did not sample $L$. griseus, $L$. montanus, L. orko or L. pulcherrimus, which were members of our L. huacahuasicus clade. Also, Aguilar-Puntriano et al. (2018) recovered $L$. fittkaui as sister to species we recovered in our $L$. dorbignyi group, whereas we recovered it in our L. huacahuasicus clade. Laurent (1986) considered L. fittkaui as part of his L. ortizi group, and we agree that there are significant morphological similarities between these species, and both species are endemic to the humid eastern Amazonian slopes of southern Peru and central Bolivia. However, none of our hypotheses recovered such a relationship. 


\section{FINAL CONSIDERATIONS}

Our phylogenetic hypotheses are the most complete to date for the L. montanus group, including more terminal taxa (56 assigned species and 37 candidate species) than any other previous analysis of the group. Our total evidence hypothesis recovers the L. montanus group as monophyletic and formed by 12 major clades, which we name as species subgroup-level clades within the $L$. montanus group. We provide lists of synapomorphies recovered for each one, including morphology, colour pattern, ecology, squamation and molecular character states. Also, we recover a series of terminal taxa that are not assignable to available species names. With the evidence of the phylogenetic results, in addition to the morphological differences found, more than five terminal taxa are currently under description, and many others are considered as candidate species.

We recognize that recent hypotheses for the L. montanus group based solely on molecular evidence lead to other conclusions regarding the evolutionary relationships of the species. Here, we base our conclusions on the total available evidence, including our observations of these organisms in their natural environments, their biogeography and ecology, and $>135$ collective years of experience with these species. In line with Hillis (2019), we urge that taxonomy must remain open to the consideration of all types of information and the examination of this through different lenses and optics. The consideration of alternative hypotheses of the evolutionary relationships of Liolaemus lizards and other organisms, based on multiple bodies of evidence, will lead to advances in our understanding of the infinitely complex evolution of biological diversity. It is precisely the unexpected or contradictory results that most enrich our discovery, debate and, ultimately, understanding.

\section{ACKNOWLEDGEMENTS}

We dedicate this work to Richard Etheridge, to thank him for his help, kindness, teaching and friendship. C.S.A. and A.S.Q. contributed equally to this work. R.V.S., A.L.B.A., J.S., M.M.P., M.R.R.-M., A.L., A.J.A.-K., R.G.P., P.V.F., J.V., S.P., R.S.C., J.A., N.G. and R.L. contributed equally to this work. We thank E. Lavilla and S. Kretzschmar (FML), F. Lobo (MCN), E. Pereyra (IBA), J. Williams (MLP), J. Faivovich (MACN), Santiago Nenda (MACN) Evaristo Lopez (MUSA), R. Aguayo and F. Valdivia (CBGR) and R. Etheridge (SDSU) for granting us access to collections under their care. We are indebted to Colección Boliviana de Fauna (CBF) of La Paz, Bolivia and we are grateful for the staffs at the Ministerio de Medio Ambiente y Agua, Viceministerio de Medio Ambiente,
Biodiversidad y Cambio Climático from Bolivia. We appreciate the field assistance of J. S. Abdala, F. S. Abdala, J. G. Abdala, M. S. Abdala, Y. Abdala; J. L. Acosta, G. Aragón, L. Arapa, D. Baldo, S. Barrionuevo, J. Bedregal, A. Brunetti, J. Cerdeña, P. Chafrat, J. C. Chaparro, F. Cruz,A. Delgado, R. Espinoza, R. Etheridge, J. Farfan, M. Halloy, L. Huamani, J. P. Juliá, F. Lobo, E. Malovini, F. Martínez, B. Miranda Calle, M. Ocampo, O. Pagaburo, J. Pizarro, V. Quequejana, A. Quiroz, E. Ramírez, M. J. Salica, G. Scrocchi, C. Stazzonelli, M. J. Tulli and E. Yampa. We thank the Abdala family for their constant logistical support in Mendoza during our trips. We thank the Yampa family (Mina Capillitas, Catamarca, Argentina); Municipality of Tolar Grande, Salta, Argentina; Antofalla village, Catamarca; and Museo de Historia Natural, San Rafael, Mendoza, for their help and support in the field. Specimens were collected under permits issued by: Argentina: APN, National Parks of Argentina; Department of Fauna, from Catamarca, Jujuy, La Pampa, Mendoza, Salta, San Juan, La Rioja and Tucumán provinces; Bolivia: Ministerio de Medio Ambiente y Agua, Viceministerio de Medio Ambiente, Biodiversidad y Cambio Climático; Servicio Nacional de Áreas Protegidas; Chile: Servicio Agrícola y Ganadero (SAG); and Perú: Servicio Nacional Forestal y de Fauna Silvestre (SERFOR). We thank to anonymous reviewer for their constructive criticisms and suggestions that have been of great help for the improvement of the manuscript. C.S.A. thanks Agencia Nacional de Promoción Científica y Tecnológica (ANPCyT), Proyectos de Investigación Científica y Tecnológica (FONCyT-PICT) 2010-2263, 2015-1398; Proyectos de Investigación Plurianuales (PIP) 0303, 2422. P.V.F. and C.S.A. thanks University of Tarapacá, Chile, Mayor de Investigación Científica y Tecnológica UTAMAYOR 4723/19, CP1799. R.G.P. and C.S.A. thanks Universidad Nacional de San Agustín de Arequipa, Perú (UNSA), IBA-0004-2017. A.L. thanks Consejo de Investigaciones Científicas y Técnicas y de Creación Artística (CICITCA) 21/E1101. We thank the Willi Hennig Society for making TNT freely available.

\section{REFERENCES}

Abdala CS. 2007. Phylogeny of the boulengeri group (Iguania: Liolaemidae, Liolaemus) based on morphological and molecular characters. Zootaxa 1538: 1-84.

Abdala CS, Juárez Heredia VI. 2013. Taxonomía y filogenia de un grupo de lagartos amenazados: el grupo de Liolaemus anomalus (Iguania: Liolaemidae). Cuadernos de Herpetología 27: 109-153.

Abdala CS, Quinteros AS. 2014. Los últimos 30 años de estudios de la familia de lagartijas más diversa de Argentina: actualización taxonómica y sistemática de Liolaemidae. Cuadernos de Herpetología 28: 55-82. 
Aguilar-Kirigin A, Abdala CS. 2016. Primer registro de Liolaemus puritamensis Núñez \& Fox, 1989 para el sur de Bolivia (Reptilia, Squamata, Liolaemidae). Cuadernos de Herpetología 30: 45-47.

Abdala V, Abdala CS, Tulli MJ. 2006. Three traditional muscular characters in the phylogeny of Liolaemus (Squamata: Tropiduridae) a reappraisal. Zootaxa 1205: 55-68.

Abdala CS, Quinteros AS, Espinoza RE. 2008. Two new species of Liolaemus (Iguania: Liolaemidae) from the Puna of northwestern Argentina. Herpetologica 64: 458-471.

Aguilar C, Wood PL Jr, Belk MC, Duff MH, Sites JW Jr. 2017. Different roads lead to Rome: integrative taxonomic approaches lead to the discovery of two new lizard lineages in the Liolaemus montanus group (Squamata: Liolaemidae). Biological Journal of the Linnean Society 120: 448-467.

Aguilar-Kirigin AJ, Abdala CS, Aparicio J, Langstroth R. 2016. Primer registro de Liolaemus pleopholis Laurent, 1998 para Bolivia (Reptilia, Squamata, Liolaemidae). Cuadernos de Herpetología 30: 89-92.

Aguilar-Puntriano C, Avila LJ, De la Riva I, Johnson L, Morando M, Troncoso-Palacios J, Wood PL Jr, Sites JW Jr. 2018. The shadow of the past: convergence of young and old South American desert lizards as measured by head shape traits. Ecology and Evolution 8: 11399-11409.

Aguilar-Puntriano C, Ramírez C, Castillo E, Mendoza A, Vargas VJ, Sites JW. 2019. Three New Lizard Species of the Liolaemus montanus Group from Perú. Diversity 11: 161.

Álvarez A, Moyers Arévalo RL, Verzi DH. 2017. Diversification patterns and size evolution in caviomorph rodents. Biological Journal of the Linnean Society 121: 907-922.

Alvarez Y, Juste J, Tabares E, Garrido-Pertierra A, Ibánez C, Bautista JM. 1999. Molecular phylogeny and morphological homoplasy in fruitbats. Molecular Biology and Evolution 16: 1061-1067.

Andrade-Díaz MS, Hibbard TN, Díaz-Gómez JM. 2017. Identifying endemism areas: an example using neotropical lizards. South American Journal of Herpetology 12: 61-75.

Aparicio J, Ocampo M. 2010. Liolaemus grupo montanus Etheridge, 1995 (Iguania-Liolaemidae). Cuadernos de Herpetología 24: 133-135.

Avila L, Morando M, Sites J Jr. 2006. Congeneric phylogeography: hypothesizing species limits and evolutionary processes in Patagonian lizards of the Liolaemus boulengeri group (Squamata: Liolaemini). Biological Journal of the Linnean Society 89: 241-275.

Bardin J, Rouget I, Cecca F. 2017. The phylogeny of Hildoceratidae (Cephalopoda, Ammonitida) resolved by an integrated coding scheme of the conch. Cladistics 33: 21-40.

Barrionuevo JS. 2017. Frogs at the summits: phylogeny of the Andean frogs of the genus Telmatobius (Anura, Telmatobiidae) based on phenotypic characters. Cladistics 33: 41-68.

Boulenger G. 1891. Description of a new lizard of the genus Ctenoblepharis, from Chili. Proceedings of the Zoological Society of London 59: 1-3.
Breitman MF, Avila LJ, Sites JW Jr, Morando M. 2011. Lizards from the end of the world: phylogenetic relationships of the Liolaemus lineomaculatus section (Squamata: Iguania: Liolaemini). Molecular Phylogenetics and Evolution 59: 364-376.

Breitman MF, Bonino MF, Sites JW Jr, Avila LJ, Morando M. 2015. Morphological variation, niche divergence, and phylogeography of lizards of the Liolaemus lineomaculatus section (Liolaemini) from southern Patagonia. Herpetological Monographs 29: 65-88.

Breitman MF, Morando M, Avila LJ. 2013. Past and present taxonomy of the Liolaemus lineomaculatus section (Liolaemidae): is the morphological arrangement hypothesis valid? Zoological Journal of the Linnean Society 168: 612-668.

Castoe TA, de Koning APJ, Kim H-M, Gu W, Noonan BP, Naylor G, Jiang ZJ, Parkinson CL, Pollock DD. 2009. Evidence for an ancient adaptive episode of convergent molecular evolution. Proceedings of the National Academy of Sciences of the United States of America 106: 8986-8991.

Cei JM. 1979. A reassessment of the genus Ctenoblepharis (Reptilia, Sauria, Iguanidae) with a description of a new subspecies of Liolaemus multimaculatus from western Argentina. Journal of Herpetology 13: 297-302.

Cei JM. 1986. Reptiles del centro, centro-oeste y sur de la Argentina. Turin: Museo Regionale di Scienze Naturali.

Cei JM. 1993. Reptiles del noroeste, nordeste y este de la Argentina: herpetofauna de las selvas subtropicales, Puna y Pampas. Turin: Museo Regionale di Scienze Naturali.

Demangel Miranda D. 2016. Reptiles en Chile. Santiago: Fauna Nativa Ediciones.

Díaz Gómez JM. 2007. Endemism in Liolaemus (Iguania: Liolaemidae) from the Argentinian Puna. South American Journal of Herpetology 2: 59-68.

Díaz-Vega RI. 2014. Range extension of Liolaemus torresi (Núñez, Navarro, Garín, Pincheira-Donosa \& Meriggio, 2003) (Squamata: Liolaemidae) in the Atacama desert, Chile. Check List 10: 1234-1236.

Engstrom TN, Shaffer HB, McCord WP. 2004. Multiple data sets, high homoplasy, and the phylogeny of softshell turtles (Testudines: Trionychidae). Systematic Biology 53: 693-710.

Escobar García P, Schönswetter P, Fuertes Aguilar J, Nieto Feliner G, Schneeweiss GM. 2009. Five molecular markers reveal extensive morphological homoplasy and reticulate evolution in the Malva alliance (Malvaceae). Molecular Phylogenetics and Evolution 50: 226-239.

Espinoza RE, Wiens JJ, Tracy CR. 2004. Recurrent evolution of herbivory in small, cold-climate lizards: breaking the ecophysiological rules of reptilian herbivory. Proceedings of the National Academy of Sciences of the United States of America 101: 16819-16824.

Esquerré D, Brennan IG, Catullo RA, Torres-Pérez F, Keogh JS. 2019. How mountains shape biodiversity: the role of the Andes in biogeography, diversification, and reproductive biology in South America's most species-rich lizard radiation (Squamata: Liolaemidae). Evolution 73: 214-230. 
Etheridge R. 1995. Redescription of Ctenoblepharys adspersa Tschudi, 1845, and the taxonomy of Liolaeminae (Reptilia, Squamata, Tropiduridae). American Museum Novitates 3142: 1-34.

Etheridge R, Frost DR. 2010. Catalogues of the pleurodont iguanian families: Liolaemidae. Version 1 (19 May 2010). Available at: http://research.amnh.org/vz/herpetology/f/ Liolaemidae.pdf (date last accessed, 7 July 2013).

Farris J. 1983. The logical basis of phylogenetic analysis. In: Platnick NI, Funk VA, eds. Advances in cladistics II. New York: Columbia University Press, 7-36.

Fontanella FM, Olave M, Avila LJ, Sites JW, Morando M. 2012. Molecular dating and diversification of the South American lizard genus Liolaemus (subgenus Eulaemus) based on nuclear and mitochondrial DNA sequences. Zoological Journal of the Linnean Society 164: 825-835.

Goloboff PA, Catalano SA. 2016. TNT version 1.5, including a full implementation of phylogenetic morphometrics. Cladistics 32: 221-238.

Goloboff PA, Farris S, Nixon K. 2000. TNT (Tree analysis using New Technology). Program and documentation. Available at: http://www.lillo.org.ar/phylogeny/tnt/ (date last accessed, 25 September 2019).

Goloboff PA, Farris JS, Nixon KC. 2008. TNT, a free program for phylogenetic analysis. Cladistics 24: 774-786.

Goloboff PA, Mattoni CI, Quinteros AS. 2006. Continuous characters analyzed as such. Cladistics 22: 589-601.

Guindon S, Gascuel O. 2003. A simple, fast, and accurate algorithm to estimate large phylogenies by maximum likelihood. Systematic Biology 52: 696-704.

Gutiérrez R, Chaparro JC, Vásquez MY, Quiroz AJ, Aguilar-Kirigin AJ, Abdala CS. 2018. Una nueva especie de Liolaemus (Iguania: Liolaemidae) de Perú, y notas sobre el grupo L. montanus. Cuadernos de Herpetología 32: 81-99.

Hillis D. 2019. Species delimitation in herpetology. Journal of Herpetology 53: 3-12.

Huelsenbeck JP, Ronquist F, Nielsen R, Bollback JP. 2001. Bayesian inference of phylogeny and its impact on evolutionary biology. Science 294: 2310-2314.

Jarvis ED, Mirarab S, Aberer AJ, Li B, Houde P, Li C, Ho SYW, Faircloth BC, Nabholz B, Howard JT, Suh A, Weber CC, da Fonseca RR, Li J, Zhang F, Li H, Zhou L, Narula N, Liu L, Ganapathy G, Boussau B, Bayzid MS, Zavidovych V, Subramanian S, Gabaldón T, Capella-Gutiérrez S, Huerta-Cepas J, Rekepalli B, Munch K, Schierup M, Lindow B, Warren WC, Ray D, Green RE, Bruford MW, Zhan X, Dixon A, Li S, Li N, Huang Y, Derryberry EP, Bertelsen MF, Sheldon FH, Brumfield RT, Mello CV, Lovell PV, Wirthlin M, Schneider MPC, Prosdocimi F, Samaniego JA, Velazquez AMV, Alfaro-Núñez A, Campos PF, Petersen B, Sicheritz-Ponten T, Pas A, Bailey T, Scofield P, Bunce M, Lambert DM, Zhou Q, Perelman P, Driskell AC, Shapiro B, Xiong Z, Zeng Y, Liu S, Li Z, Liu B, Wu K, Xiao J, Yinqi X, Zheng Q, Zhang Y, Yang H, Wang J, Smeds L, Rheindt FE, Braun M, Fjeldsa J, Orlando L, Barker FK, Jønsson KA, Johnson W, Koepfli K-P, O'Brien S, Haussler D, Ryder OA,
Rahbek C, Willerslev E, Graves GR, Glenn TC, McCormack J, Burt D, Ellegren H, Alström P, Edwards SV, Stamatakis A, Mindell DP, Cracraft J, Braun EL, Warnow T, Jun W, Gilbert MT, Zhang G. 2014. Whole-genome analyses resolve early branches in the tree of life of modern birds. Science 346: 1320-1331.

Jiménez-Robles O, Butron-Galvez $\mathbf{P}$, Carpio $\mathbf{R}$, de la Riva I. 2016. Revised distribution, phenotypic variation and conservation status of Liolaemus fittkaui (Squamata: Liolaemidae), a lizard endemic to the Andes of Central Bolivia. Phyllomedusa 15: 7-20.

Kumar S, Stecher G, Tamura K. 2016. MEGA7: molecular evolutionary genetics analysis version 7.0 for bigger datasets. Molecular Biology and Evolution 33: 1870-1874.

Laurent RF. 1982. Las especies y "variedades" de Liolaemus descritas por J. Koslowsky (Sauria Iguanidae). Neotropica (La Plata) 28: 87-96.

Laurent RF. 1983. Contribución al conocimiento de la estructura taxonómica del género Liolaemus Wiegmann (Iguanidae). Boletín de la Asociación Herpetológica 1: $16-18$

Laurent RF. 1985. Segunda contribución al conocimiento de la estructura taxonómica del género Liolaemus Wiegmann (Iguanidae). Cuadernos de Herpetología 1: 1-37.

Laurent RF. 1986. Descripciones de nuevas Iguanidae del genero Liolaemus. Acta Zoologica Lilloana 38: 87-105.

Laurent RF. 1991. Sobre algunas especies nuevas y poco conocidas de Liolaemus (Iguanidae) de la provincia de Jujuy, Argentina. Acta Zoológica Lilloana 40: 91-108.

Laurent RF. 1995. Sobre una pequeña colleción de lagartos del género Liolaemus (Tropiduridae) proviniente del extremo suroeste de Bolivia. Cuadernos de Herpetología 9: 1-6.

Langstroth R. 2011. On the species identities of a complex Liolaemus fauna from the Atiplano and Atacama Desert: insights on Liolaemus stozmanni, L. reichei, L. jamesi pechecoi, and L. poconchilienis (Squamata: Liolaemidae). Zootaxa 2809: 20-32.

Lobo F. 2001. A phylogenetic analysis of lizards of the Liolaemus chiliensis group (Iguania: Tropiduridae). Herpetological Journal 11: 137-150.

Lobo F. 2005. Las relaciones filogenéticas dentro del grupo chiliensis (Iguania: Liolaemidae: Liolaemus): sumando nuevos caracteres y taxones. Acta Zoológica Lilloana 49: 65-87.

Lobo F, Espinoza RE. 1999. Two new cryptic species of Liolaemus (Iguania: Tropiduridae) from northwestern Argentina: resolution of the purported reproductive bimodality of Liolaemus alticolor. Copeia 1999: 122-140.

Lobo F, Quinteros S. 2005. A morphology-based phylogeny of Phymaturus (Iguania: Liolaemidae) with the description of four new species from Argentina. Papéis Avulsos de Zoologia (São Paulo) 45: 143-177.

Lobo F, Slodki D, Valdecantos S. 2010a. Two new species of lizards of the Liolaemus montanus group (Iguania: Liolaemidae) from the northwestern uplands of Argentina. Journal of Herpetology 44: 279-293.

Lobo F, Espinoza RE, Quinteros AS. 2010b. A critical review and systematic discussion of recent classification proposals for liolaemid lizards. Zootaxa 2549: 1-30. 
Medina CD, Avila LJ, Sites JW Jr, Morando M. 2014. Multilocus phylogeography of the Patagonian lizard complex Liolaemus kriegi (Iguania: Liolaemini). Biological Journal of the Linnean Society 113: 256-269.

Mirande JM. 2008. Filogenia de la familia Characidae (Teleostei: Characiformes). Unpublished Ph.D. Thesis, Universidad Nacional de Tucumán.

Mirande JM. 2009. Weighted parsimony phylogeny of the family Characidae (Teleostei: Characiformes). Cladistics 25: 574-613.

Mirande JM. 2010. Phylogeny of the family Characidae (Teleostei: Characiformes): From characters to taxonomy. Neotropical Ichthyology 8: 385-568.

Morando M. 2004. Sistemática y filogenia de grupos de especies de los géneros Phymaturus y Liolaemus (Squamata: Tropiduridae: Liolaeminae) del oeste y sur de Argentina. Unpublished Ph.D. Thesis, Universidad Nacional de Tucumán.

Morando M, Avila LJ, Turner CR, Sites JW Jr. 2007. Molecular evidence for a species complex in the Patagonian lizard Liolaemus bibronii and phylogeography of the closely related Liolaemus gracilis (Squamata: Liolaemini). Molecular Phylogenetics and Evolution 43: 952-973.

Mott T, Vieites DR. 2009. Molecular phylogenetics reveals extreme morphological homoplasy in Brazilian worm lizards challenging current taxonomy. Molecular Phylogenetics and Evolution 51: 190-200.

Mueller RL, Macey JR, Jaekel M, Wake DB, Boore JL. 2004. Morphological homoplasy, life history evolution, and historical biogeography of plethodontid salamanders inferred from complete mitochondrial genomes. Proceedings of the National Academy of Sciences of the United States of America 101: 13820-13825.

Nunez H, Yanez J. 1983. Ctenoblepharis audituvelatus new species, a lizard from northern Chile (Reptilia Iguanidae). Copeia 1983: 454-457.

Núñez H, Fox SF. 1989. Liolaemus puritamensis, a new species of iguanid lizard previously confused with Liolaemus multiformis (Squamata: Iguanidae). Copeia 1989: 456-460.

Núñez H, Jaksic F. 1992. Lista comentada de los reptiles terrestres de Chile continental. Boletín del Museo Nacional de Historia Natural de Chile 43: 63-91.

Núñez H, Navarro J, Garín C, Pincheira-Donoso D, Meriggio V. 2003. Phrynosaura manueli y Phrynosaura torresi, nuevas especies de lagartijas para el norte de Chile (Squamata: Sauria). Boletín del Museo Nacional de Historia Natural, Chile 52: 67-88.

Núñez H, Veloso A. 2001. Distribución geográfica de las especies de lagartos de la Región de Antofagasta, Chile. Boletín del Museo Nacional de Historia Natural 50: 109-120.

Olave M, Avila LJ, Sites JW Jr, Morando M. 2014. Multilocus phylogeny of the widely distributed South American lizard clade Eulaemus (Liolaemini, Liolaemus). Zoologica Scripta 43: 323-337.

Ortiz J. 1981. Estudio multivariado de las especies de Liolaemus del grupo nigromaculatus (Squamata, Iguanidae). Anales del Museo de Historia Natural de Valparaíso 14: 247-265.

Paz MM. 2012. Actualización filogenética del grupo de Liolaemus boulengeri (Iguania: Liolaemidae). Unpublished bachelor Thesis, Universidad Nacional de Tucumán.
Paz MM, Semhan RV, Abdala CS. 2013. Ampliación del área de distribución de Liolaemus cazianae (Lobo, Slodky \& Valdecantos, 2010) en la Provincia de Salta (Argentina). Cuadernos de Herpetología 27: 177-178.

Pincheira-Donoso D. 2002. Revisión crítica de las especies de Liolaemus Wiegmann, 1834 del grupo ruibali (Sauria: Tropiduridae: Liolaeminae). Concepción: Unidad de Investigación, Facultad Ciencias Natural y Oceanografía, Universidad de Concepción.

Pincheira-Donoso D. 2014. No evidence for conspecificity between two high Andes Liolaemus lizards (Squamata: Liolaemidae). Acta Herpetologica 9: 249-252.

Pincheira-Donoso D, Núñez H. 2002. Situación taxonómica de Liolaemus ornatus Koslowsky, 1898 y Liolaemus pantherinus Pillegrin, 1909 (Sauria, Tropduridae, Liolaemidae). Noticiario mensual, Museo Nacional de Historia Natural 350: 38-42.

Pincheira-Donoso D, Núñez H. 2005. Les especies Chilenas del género Liolaemus Wiegmann, 1834 (Iguania:Tropiduridae: Liolaeminae): taxonomía, sistemática y evolución. Santiago: Museo Nacional de Historia Natural Chile.

Pincheira-Donoso D, Scolaro JA, Sura P. 2008. A monographic catalogue on the systematics and phylogeny of the South American iguanian lizard family Liolaemidae (Squamata, Iguania). Zootaxa 1800: 1-85.

Portelli SN, Quinteros AS. 2018. Phylogeny, time divergence, and historical biogeography of the South American Liolaemus alticolor-bibronii group (Iguania: Liolaemidae). PeerJ 6: e4404.

Posada D. 2008. jModelTest: phylogenetic model averaging. Molecular Biology and Evolution 25: 1253-1256.

Pyron RA, Burbrink FT, Wiens JJ. 2013. A phylogeny and revised classification of Squamata, including 4161 species of lizards and snakes. BMC Evolutionary Biology 13: 93.

Quinteros AS. 2012. Taxonomy of the Liolaemus alticolorbibronii Group (Iguania: Liolaemidae), with descriptions of two new species. Herpetologica 68: 100-120.

Quinteros AS. 2013. A morphology-based phylogeny of the Liolaemus alticolor-bibronii group (Iguania: Liolaemidae). Zootaxa 3670: 001-032.

Quinteros AS, Abdala CS, Lobo FJ. 2008. Redescription of Liolaemus dorbignyi Koslowsky, 1898 and description of a new species of Liolaemus (Iguania: Liolaemidae). Zootaxa 1717: 51-67.

Quinteros AS, Díaz Gómez JM. 2011. Diversidad y endemismos en la Puna del NOA. Temas de Biología y Geología del NOA 1: 58-64.

Quinteros AS, Abdala CS. 2011. A new species of Liolaemus of the Liolaemus montanus section (Iguania: Liolaemidae) from northwestern Argentina. Zootaxa 2789: 35-48.

Ronquist F, Huelsenbeck JP. 2003. MrBayes 3: Bayesian phylogenetic inference under mixed models. Bioinformatics 19: $1572-1574$.

Ruiz de Gamboa Astroza M, González MF. 2013. Liolaemus stolzmanni (Steindachner, 1891) (Squamata: Liolaemidae): distribution update. Check List 9: 1067-1069.

Schulte JA II. 2013. Undersampling taxa will underestimate molecular divergence dates: an example from the South American lizard clade Liolaemini. International Journal 
of Evolutionary Biology 2013: 1-12. Article ID: 628467. doi:10.1155/2013/628467

Schulte JA II, Macey JR, Espinoza RE, Larson A. 2000. Phylogenetic relationships in the iguanid lizard genus Liolaemus: multiple origins of viviparous reproduction and evidence for recurring Andean vicariance and dispersal. Biological Journal of the Linnean Society 69: 75-102.

Schulte JA II, Melville J, Larson A. 2003a. Molecular phylogenetic evidence for ancient divergence of lizard taxa on either side of Wallace's Line. Proceedings of the Royal Society B: Biological Sciences 270: 597-603.

Schulte JA II, Valladares JP, Larson A. 2003b. Phylogenetic relationships within Iguanidae inferred using molecular and morphological data and a phylogenetic taxonomy of iguanian lizards. Herpetologica 59: 399-419.

Schulte JA II, Losos JB, Cruz FB, Núñez H. 2004. The relationship between morphology, escape behaviour and microhabitat occupation in the lizard clade Liolaemus (Iguanidae: Tropidurinae: Liolaemini). Journal of Evolutionary Biology 17: 408-420.

Steindachner F. 1891. Über einege neue und seltene Reptilien- und Amphibien-Arten. Sitzungsberichte der Kaiserlichen Akademie der Wissenschaften, Mathematisch Naturwissenschaftliche Classe 100: 289-314.

Thiele K. 1993. The holy grail of the perfect character: the cladistic treatment of morphometric data. Cladistics 9: 275-304.

Troncoso-Palacio J. 2014. Revisión del estatus taxonómico de Liolaemus filiorum Pincheira-Donoso y Ramírez, 2005 (Iguania: Liolaemidae). Cuadernos de Herpetología 28: 1-7.
Troncoso-Palacios J, Ferri-Yáñez F. 2013. Liolaemus patriciaiturrae Navarro and Núñez, 1993 (Squamata: Liolaemidae): distribution extension in northern Chile and geographic distribution map. Check List 9: 78-80.

Valladares JP, Etheridge R, Schulte J II, Manriquez G, Spotorno A. 2002. Nueva especie de lagartija del norte de Chile, Liolaemus molinai (Reptilia: Liolaeminae). Revista Chilena de Historia Natural 75: 473-489.

Valladares P, Etheridge R, Abdala CS. 2018. Resurrection and redescription of Liolaemus reichei, proposal of a Neotype to stabilization of the taxonomy. Revista Mexicana de Biodiversidad. 89: 393-401.

Veloso A, Navarro J. 1988. Lista systemática y distribución geográfica de anfibios y reptiles de Chile. Bollettino Museo Regionale di Scienze Naturali Torino 6: 481-539.

Werner F. 1907. Estudios sobre reptiles chilenos. Anales de la Universidad de Chile 121: 147-155.

Wiens JJ. 1995. Polymorphic characters in phylogenetic systematics. Systematic Biology 44: 482-500.

Young-Downey AR. 1998. Phylogenetic studies on Liolaemus (Sauria: Tropiduridae): an interpretation based on molecular data and a biochemical test of a biogeographic hypothesis. Unpublished Ph.D. Thesis. Coral Gables, Florida: University of Miami.

Zheng Y, Wiens JJ. 2016. Combining phylogenomic and supermatrix approaches, and a time-calibrated phylogeny for squamate reptiles (lizards and snakes) based on 52 genes and 4162 species. Molecular Phylogenetics and Evolution 94: $537-547$.

\section{SUPPORTING INFORMATION}

Additional Supporting Information may be found in the online version of this article at the publisher's web-site:

Appendix S1. List of specimens studied.

Appendix S2. List of characters used from other studies.

Appendix S3. Accesion numbers of GenBank sequences of the specimens included.

Appendix S4. List of used characters.

Figure 1 S4. Scales of head and ventral regions of body used in this study. A, pink, infralabials; orange, supralabials; red, lorilabials; light blue, nasal; purple, canthal; gold, preocular; blue, subocular; green, postocular; yellow, character 14, number of scales contacting the second infralabial ventrally. B, purple, internasals; yellow, postrostrals; red, rostral; blue, mental (black dashed line, mental pore); green, chin shields; pink, scales between fourth chin shields. C, grey, mental scale; yellow, gular region; light blue, neck (between forelimbs); orange, chest; purple, belly; green, waist; blue, groin; red, tail base; pink, character 27 (number of pygals).

Figure 2 S4. Characters of head scales. A, shape of upper temporals (character 52). Liolaemus fabiani (left); Liolaemus annectens (centre); Liolaemus dorbignyi (right). See text for details. B, lower ciliaries (characters 57-59) and superciliaries (character 60). Liolaemus aff. huayra (left); Liolaemus torresi (right). See text for details. C, postocular scale (character 62). Liolaemus scrocchii (left); Liolaemus multicolor (right). See text for details.

Figure 3 S4. Some scale shape characters. A, infralabials (character 63). Liolaemus aff. jamesi (left); Liolaemus audituvelatus (right). See text for details. B, scales of occiput (character 64). Liolaemus patriciaiturrae (left); Liolaemus pachecoi (right). See text for details. C, heteronotes on dorsum (character 82). Liolaemus montanus (left); Liolaemus puritamensis (centre); Liolaemus jamesi (right). See text for details.

Figure 4 S4. Characters of forelimb scales. A, female of Liolaemus jamesi (characters 90, 91 and 93) and scales around forelimbs (character 94). B, Liolaemus huacahuasicus. Arm and forearm (characters 96-99). 
Figure 5 S4. Characters from scales of gular and antehumeral region. A, Liolaemus aff. huayra. Scales of forelimb (character 93) and antehumeral scales (character 100). B, Liolaemus molinai. Enlarged scales on sides of antehumeral fold (character 101) and enlarged central scale on gular region (character 132).

Figure 6 S4. Characters of palmar scales. Palmar scales (characters 102-104). Liolaemus aff. jamesi (left); Liolaemus torresi (right).

Figure 7 S4. Characters of pores on ventral regions. A, ventral region of thigh (character 117). B, gular region (character 126). C, pectoral region (character 133). D, sides of belly (character 135). Liolaemus porosus.

Figure 8 S4. Region of body where pores were scored: thighs (character 117); base of tail (character 122); mental region (character 124); gular (character 126); pectoral region (character 133); sides of belly (character 135); waist (character 137). Liolaemus torresi.

Figure 9 S4. Characters of pygal region: supernumerary pores (character 138) and scales of pygal region (characters 140 and 141). Liolaemus aff. jamesi (left); Liolaemus torresi (right).

Figure 10 S4. Characters of male coloration. A, Liolaemus pachecoi (characters 144, 148, 160, 187, 191, 195, 202 and 209). B, Liolaemus puritamensis (characters 145, 146, 180 and 202). C, Liolaemus molinai (characters 151, 176, 174, 181 and 197). D, Liolaemus pulcherrimus (characters 153-155, 172 and 205). E, Liolaemus multicolor (characters 162, 203 and 208).

Figure 11 S4. Characters of male coloration. A, Liolaemus patriciaiturrae (characters 156, 157, 168, 177 and 198). B, Liolaemus aff. torresi (characters 168 and 177). C, Liolaemus cazianiae (character 168). D, Liolaemus porosus (characters 157 and 168). E, Liolaemus dorbignyi (characters 156, 157 and 168). F, Liolaemus etheridgei (characters 168, 177 and 195). G, Liolaemus aff. huayra (characters 168 and 177). H, Liolaemus andinus (characters 156, 157 and 168). I, Liolaemus insolitus (characters 156, 157 and 168).

Figure 12 S4. Characters of male coloration. A, Liolaemus jamesi (characters 159, 161, 191 and 194). B, Liolaemus islugensis (characters 164, 171, 179, 181, 197 and 201). C, Liolaemus cazianiae (characters 163, 181, 188, 199 and 204). D, Liolaemus inti (characters 165, 197 and 199). E, Liolaemus signifer (characters 173, 181, 186 and 191). F, Liolaemus schmidti (characters 174, 181, 200 and 206). G, Liolaemus foxi (characters 183, 184, 193 and 199). H, Liolaemus ruibali (characters 192 and 196).

Figure 13 S4. Characters of ventral coloration in males. A, Liolaemus cazianiae (characters 211, 213, 219, 226 and 232). B, Liolaemus aff. jamesi3 (characters 213, 216, 229 and 232). C, Liolaemus aymararum (characters 212 , 213, 219, 226, 229 and 232). D, Liolaemus insolitus (characters 210, 213, 215, 221, 226 and 232). E, Liolaemus aff. huayra (characters 215, 216, 219, 226, 228 and 234). F, Liolaemus nigriceps (characters 210, 215, 223, 228 and 235).

Figure 14 S4. Sexual dichromatism evident. A, B, male of Liolaemus gracielae. C, D, female of Liolaemus gracielae. Figure 15 S4. Character of female coloration. A, specimen without colour pattern (character 238). Liolaemus multicolor. B, spots on lateral field (character 261). Liolaemus montanus.

Figure 16 S4. Lateral spots on females. Fused lateral spots forming stripes (character 263). A, Liolaemus fabiani. B, Liolaemus multicolor. C, Liolaemus aff. foxi.

Figure 17 S4. Character 287. Habitat of the species of Liolaemus montanus group.

Table S1. List of synapomorphies for the total evidence hypothesis. 